\title{
JUDICIAL UNIFICATION IN POST-COLONIAL INDONESIA
}

\author{
Danie1 S. Lev
}

The reason for writing this article is to pull together scattered materials on the growth of a national judiciary in Indonesia during the Japanese occupation, the revolution, and early independence, and to put these materials in some perspective more useful than a merely legal one. This perspective is not in the first place a functional one, since the history of judicial integration had relatively little to do with the explicit work of courts. What it did have to do with, more than anything else, was the adoption of (and conflict over) new institutional symbols of authority that favored new ruling groups and new political and social visions.

Historically courts have often been among the earliest institutions to attract the attention of national unifiers. It is tempting, under the influence of both Marx and Weber, to argue that the reasons are fundamentally economic. But while economic advantages undoubtedly flow from centrally controlled judiciaries, the case for the economic inspiration of judicial unification tends to be indirect and overly abstract. ${ }^{1}$ There is not much evidence that when political leaders have decided to extend the judicial authority of the crown or state, they have thought immediately and above all of regularity, certainty, and economic control. Other administrative institutions are better than courts at that sort of thing. What is more impressive about the judiciary is that it is an obvious symbol of authority, the putative keeper of peace and dispenser of justice.

Recently, at least, in former colonies the primary impetuses to judicial unification have been ideological and poltiica1. ${ }^{2}$ To start with, there are reactions against divisive colonial orders, manifested more or less accurately in colonial legal organization, in which judicial pluralism inevitably contained an invidious distinction between "advanced" Europeans and "backward" natives. In addition, nationalist political and intellectual leaders have aspired to both political integration and "modernization," for whose achievement legal unification is almost universally regarded as a necessary step. If nothing else, the law is political framework and symbolically represents the order of society. Judicial unification, by this reasoning, logically becomes a prior urgency. Once unified, national courts tend to be inspired

1. See M. Rheinstein (ed.), Max Weber on Law in Economy and Society (Cambridge: Harvard University Press, 1954), and David M. Trubek, "Max Weber on Law and the Rise of Capitalism," Wisconsin Law Review, MCMLXXII, No. 3 (1972), pp. $686 \mathrm{ff}$. (reprinted as Yale Law School Studies in Law and Modernization No. 4).

2. For a brief review of the unification of courts in African states, see Thierry Verhelst, "Safeguarding African Customary Law: Judicial and Legislative Processes for its Adaptation and Integration" (Los Angeles: University of California, African Studies Center, Occasional Paper No. 7, 1968). 
by the impulses that promoted them in the first place--above all, national unity. ${ }^{3}$ It is not surprising, for one thing, that new national judges, like other leaders, soon blur distinctions between customary legal traditions, which colonial courts had maintained and nourished. Not long after independence, the defense of traditional law, apart from occasional lip service, is left to anxious local leaders, legal romantics, and foreign scholars in the habit of distinguishing law from politics.

The urge to unity represents in part a search for political resources, which in new states are usually widely diffused. Behind the tensions of unification, whether of courts or of administration generally, is a struggle between new national elites and older local elites. The history of such perennial conflict in Europe, China, and Japan has been well documented. In the colonies of Africa and Asia, the major historical factor not present in Europe has been the lengthy foreign protection, even the creation, of local elites outfitted with locally oriented governing institutions. Whether or not this altered the character of the conflict, it made its joining more abrupt. In some cases the battle has been bloody. Fanon has summed up this eventuality:

We have said that the native's violence unifies the people. By its very structure, colonialism is separatist and regionalist. Colonialism does not simply state the existence of tribes; it also reinforces it and separates them. The colonial system encourages chieftaincies and keeps alive the old Marabout confraternities. Violence is in action all-inclusive and national. It follows that it is closely involved in the liquidation of regionalism and of tribalism. Thus, the national parties show no pity at all towards the caids and the customary chiefs. Their destruction is the preliminary to the unification of the people. ${ }^{4}$

It is not only that the existence of powerful local elites denies a relatively new, poorly organized, and insecure national elite the fullness of power. To leadership groups asserting demands for political and social change, local power seems hopelessly conservative. It usually is, for local groups in new states are under pressure to give up control over their own lives for the sake of a larger and less meaningful collectivity whose benificence is in doubt. Between these two perspectives compromise is hard to work out, because so much is at stake. On both the material and symbolic levels of action, law and legal institutions are inevitably involved; what is contested is legitimate authority to make law and to apply it.

There are at least three possible processes of institutional unification. One is gradual and evolutionary, in which spatially dispersed but functionally similar institutions come together under economic and political pressure or in which one institution expands, absorbing or eliminating all others performing the same functions. The expansion of royal administration in Norman England is an example. Another basic type of development is one in which an elite is enabled by overwhelming organizational power to impose new institutions upon a society whether or not it is receptive. Colonial history offers examples of this

3. See, for example, William Burnett Harvey, Law and Social Change in Ghana (Princeton: Princeton University Press, 1966), p. 151.

4. Frantz Fanon, The Wretched of the Earth (New York: Grove Press, 1966), p. 73. 
pattern of unification; so does Japan after the Meiji restoration. The third major type of unification, implied in the quote from Fanon, is revolutionary. In this case, varying with the ideological origins and territorial extent of the revolution, unification of administrative and political institutions may be accomplished very rapidly. In the great revolutions of modern times--France, the Soviet Union, China--new ruling groups were able to grasp the opportunities offered by social turmoil and mobilization to bring about radical institutional changes in society. Revolutionary mobilization makes abrupt change possible, because people are more likely then to be receptive to new institutions. ${ }^{5}$ In the first instance of their acceptance under revolutionary conditions, unified institutions may serve primarily a symbolic purpose, one of popular identification with the new state. At this stage of change local elites must join the national cause, quietly withdraw, or be eliminated, but in any event their ancient institutional equipment will be likely to disappear. At a later stage, when the revolution has been consolidated and new institutions must consistent1y perform the functions expected of them, another process of adjustment is necessary in which national and local aspirations again may clash. The outcome depends upon the resources available to each side.

Judicial unification in Indonesia involved elements of all three kinds of change mentioned above. Along a vertical axis colonial judicial arrangements predicated upon racial distinctions were eliminated during the Japanese occupation. Customary courts, representing the horizontal differentiation of Indonesian society, collapsed in two stages: one violent, during the revolution, the other later and more gradual, but resulting from revolutionary causes. Unification was (and still is) incomplete, however, in that Islamic courts survived. The essential difference between Islamic and customary courts, the reason why the former survived and the latter did not, is political. While Islamic political power was mobilized nationally to defend Islamic institutions, no such mobilization of traditional local forces ever became possible. 6

From the turn of the twentieth century until the Japanese invasion in 1942, legal and judicial unification was a constant issue in the colony. Statutory law had been unified for all population groups only in a very few areas of activity. The pace seemed to quicken when in 1914 a misdemeanors court (Zandgerecht) was created for all residents of the colony, and in 1918 a common criminal code was promulgated, the biggest step yet in statutory unification. But significantly no common code of criminal procedure appeared, and when the colonial period ended al1 that had been done along these iines was to revise and improve the existing procedural code for Indonesians.?

5. See Karl Deutsch, "Social Mobilization and Political Development," American Political Science Review, 55 (1961). Also, by way of case studies, John T. McAlister, Jr., Viet Nam: The Origins of Revolution (New York: Knopf, 1969); Chalmers Johnson, Peasant Nationalism and Communist Power (Stanford: Stanford University Press, 1962); Franz Schurmann, Ideology and Organization in Communist China (2nd ed.; Berkeley and Los Angeles: University of California Press, 1968).

6. On the Islamic judiciary, which will not be dealt with here at any length, see Daniel S. Lev, Islamic Courts in Indonesia (Berkeley and Los Angeles: University of California Press, 1972).

7. Herziening van het strafprocesrecht (Batavia: Landsdrukkerij, 1940-41), the official report on the revision of criminal procedure undertaken during the last few 
The initial impetus for unification across racial and ethnic 1 ines came from colonial liberalism and the Ethical movement, neither of which endured long in the twentieth century. Dutch adat law scholars, themselves deeply influenced by Ethical tenets but also perhaps by the concepts of continental historical jurisprudence, were able to stem the tide of unification in the $1920^{\prime} \mathrm{s} .{ }^{8}$ Thereafter colonial policy rein forced ethnic cleavages in Indonesia. Customary judicial institutions were strengthened, main1y outside of Java, and where they had 1ong since atrophied attempts were sometimes made to revive them. The logical development of these policies was partially blocked by the assertion of control over customary institutions by Dutch Binnenlands Bestuur officials, whose position was favored by the failure of the Ethical movement during the last two decades of the colony and the vigorous re-emergence of the colonial Beamtenstaat (Administrative State). ${ }^{9}$

Throughout this period, the final years of the colony, the unificatiedrang (drive to unification) had if anything grown stronger among the Indonesian elite. 10 But they did not object, in the first instance, to the horizontal differentiation of ethnic groups or to the maintenance of traditional adat institutions. There were indeed some Indonesian leaders, including professional lawyers, who opposed adat courts for their backwardness--as well as the divided political condition they symbolized--and insisted that they be replaced by modern secular courts. Those who raised this issue, however, were as likely as not to be from outside of Java. In Java itself, where the government judiciary had long predominated and traditional courts remained only in three of the four royal kraton (palaces), adat courts were much less a

years of colonial rule. A new procedural code for Indonesians--the Herziene Inlandsch (Indonesisch) Reglement, Revised Native Regulation--when into effect in major cities of Java in mid-1941. A separate code applied to areas outside of Java and Madura.

8. See C. van Vollenhoven, De Ontdekking van het Adatrecht (Leiden: Brill, 1928); Supomo and Djokosutono, Sedjarah Politik Hukum Adat (2 vols.; Djakarta: Djambatan, 1950); Harry J. Benda, The Crescent and the Rising Sun: Indonesian Islam under the Japanese Occupation, 1942-1945 (The Hague and Bandung: van Hoeve, 1958). On judicial structure in the colony, see the introduction by Schiller and Hoebel to the English translation of B. ter Haar's Adat Law in Indonesia (New York: Institute of Pacific Relations, 1948).

9. Harry J. Benda, "The Pattern of Administrative Reforms in the Closing Years of Dutch Rule in Indonesia," The Journal of Asian Studies, XXV, No. 4 (August 1966). Similarly, in the independent state an effort to abolish the centrally-directed regional administration, the pamong praja, failed in the $1950^{\prime} \mathrm{s}$.

My own interviews with men who had served as judges on adat courts before the war in Tapanuli, East Sumatra, South Sumatra, Bali, and Lombok indicate that the local Dutch controleur and the resident, who exercised review powers over local courts, had great influence over decisions of the courts. Apparently the controleur or his representative was normally present at sessions of the adat courts, and that in itself would have altered the atmosphere of the hearings.

10. See Verslag van de Commissie tot bestudeering van staatsrechtelijke hervormingen (Batavia: Landsdrukkerij, 1941-42), the report of the constitutional reform commission established in 1940, especially Vol. II, pp. $42 \mathrm{ff}$. and $59 \mathrm{ff}$. 
concern. Many Javanese lawyers, moreover, fully supported the adat-law views of their teachers, van Vollenhoven and ter Haar, and were sympathetic to the protection of customary institutions. Apart from this perspective, Indonesian lawyers were perhaps ambivalent about unification when it came to such problematic areas of substantive 1 aw as that of the family and 1 and. In any event, it was not the horizontal cleavage between Indonesian ethnic groups but the vertical one between major racial divisions in the colony--and the distinctions were vertical despite Dutch efforts to portray them as horizontal--that drew the primary attention of the Indonesian (and Chinese) elite. They favored unification of legal institutions whenever legal differentiation implied a superior-inferior relationship, which it usually did in the context of colonial pluralism. The major thrust of the unificatiedrang in the $1930^{\prime} \mathrm{s}$ was therefore to eradicate racial distinctions inherent in colonial law. 1 But little was done about this before the colony came to an end. Nor does any evidence indicate that much more would have been done soon, despite Dutch intellectual sympathy for an antiracialist position.

When the Japanese army invaded in 1942, Indonesian leaders stil1 had at least this kind of unification in mind. It was accomplished during the occupation.

\section{The Japanese Occupation}

Ine outlook of the Japanese military government on matters of law and administration was rather like that of the Dutch, and as the occupation wore on it became even more so. 12 Few major structural changes were contemplated other than the utter obliteration of Dutch authority and its replacement by Japanese authority. For ease of administration most existing laws and regulations were kept in force. "Native chiefs and officials displaying a sincere desire to cooperate with Japan" were to be employed as much as possible, and, like the Dutch before them, "local customs, practices, and religions shall not be interfered

11. See ibid. for a detailed discussion of racial distinctions in the colonial legal system. In a piece written in English and entitled "The Divide et Impera Policy of the Dutch Government in Law and Order," dated January 31, 1944 and possibly intended as a lecture or report for the Committee on Adat and Traditional Administration established by the Japanese military government, Professor Supomo, the most prominent Indonesian adat law scholar, concentrated entirely on racial distinctions and discrimination in the colony. No mention at all was made of colonial adat law policies, to which Supomo had formerly been committed but which he later, during and after the revolution, began to see as inimical to national integration and modernization. The above-mentioned manuscript was found among the Supomo papers in the Ministry of Justice. I am grateful to the Ministry for permission to examine the documents.

12. For background material on the occupation, see especially B. R. O'G. Anderson, "Japan: 'The Light of Asia,"" in J. Silverstein (ed.), Southeast Asia in World War II: Four Essays (New Haven: Yale University, Southeast Asia Studies, 1966), and Benda, The Crescent and the Rising Sun. Also specifically on judicial matters, 0erip Kartodirdjo, "De rechtspraak op Java en Madoera tijdens de Japanse bezetting 1942-1945," Indisch Tijdschrift van het Recht (Apri1 1947), pp. 8-21, and R. Tresna, Peradilan di Indonesia dari Abad ke Abad (Amsterdam and Djakarta: Versluys, 1957). 
with for the time being." 13 Further, "in matters concerning native civil affairs, their customs and mores should be carefully respected, and particular care is necessary so as not to provoke needless animosity and discord."14

Significant changes did occur in judicial organization, however, partly as a by-product of the elimination of Dutch officials from public life. The form of these changes was influenced both by the Japanese example of unified courts and by the advice of Indonesian lawyers, especially the adat scholar Professor Supomo, who were appointed to positions in the occupation administration. 15 During the first few months of the occupation, the courts simply stopped working, because of the incarceration of Dutch judges and prosecutors and the existence of widespread uncertainty. But by September 1942 the military govern-

13. "Outline of the Conduct of Military Administration in Occupied Areas," March 14, 1942, a Japanese Ministry of the Navy document, in Harry J. Benda, James K. Irikura, and Kōichi Kishi, Japanese Military Administration in Indonesia: Selected Documents (New Haven: Yale University, Southeast Asia Studies, 1965), p. 29. Indonesia was divided up among three different commands during the occupation, one in Jakarta for Java and Madura, one in Singapore that included Sumatra, and a Navy comnland in Makasar that administered the rest of Indonesia.

14. "Instructions of the Superintendent-General of Military Administration," August 7, 1942, from the Singapore headquarters, in ibid, p. 188.

15. In September 1942 the military government created an interesting body called the Panitia Adat dan Tatanegara Dahulu, the Committee on Adat and Traditional Administration, to which a number of Japanese and prominent Indonesians were appointed. The purpose of this committee was at first ambiguous. It was intended partly as a research organization that would advise the occupation government on the traditions and character of Javanese society. But it was also "to function as an agency for the wide expression of public sentiment," for which purpose five Javanese political leaders were attached to the committee, including Soekarno, Hatta, Soekardjo Wirjopranoto, K. H. Mansur and Wondoamiseno. See document no. 33 on the decision to establish the committee, dated September 24, 1942, in ibid., pp. 133-35. Also the daily Asia Raya, November 9 and 10, 2602 (1942). The political functions of the committee were taken over shortly by other organizations, and it was divided into several subcommittees dealing with various social and economic problems, only one of which was adat and traditional administration. Indonesian members of the research staff of the committee included Professor Supomo, Professor Djajadiningrat (Indonesia's most prominent scholar of Islam), Professor Poerbatjaraka (a famous student of Javanese history and literature), Mansur (an Islamic leader), Hatta, and $\mathrm{K}$. $\mathrm{H}$. Dewantara (a nationalist educator). Japanese members of the committee included several high-ranking civil servants, diplomats, and journalists, some of whom had been in Java for years prior to the occupation. The chairman was K. Hayashi, formerly in the Ministry of Foreign Affairs and considered an expert on the "southern areas." Asia Raya, November 10, 1942. Whatever Japanese intentions were for the committee, Supomo, who led the adat subcommittee, seems to have viewed it like a prewar research group. He tried to get more research done on Javanese adat, particularly in East Java, the only area of Java on which a major volume had not yet been published. Supomo's scholarly methods were evidently too painstaking for Japanese purposes, and some tension arose in the subcomittee over the speed with which its tasks had to be completed and indeed exactly what kind of work it should do. At the very least, the subcommittee served as a forum for the legal views of Supomo and other lawyers, and as an arena in which adat scholars and supporters of Islam clashed time and again. 
ment in Java had promulgated a series of laws reconstructing the judiciary. ${ }^{16}$ The end result was a vertically unified secular judiciary. It included the old districtsgerecht (now Gun Hoin), regentschaps'recht (Ken Hōin), Zandgerecht (Keizai Hōin), landraad (Tihō Hōin), Raad van Justitie (Kōtō Hōin), and Hooggerechtshof (Saikō Hōin). 17 nnly the former residentiegerecht had actually disappeared, but all courts now served the same clientele. Japanese nationals alone were txcepted from the general jurisdiction. During the revolution the Gun Hō:n, Ken Hōin, and Keizai Hōin were absorbed by the Tihō Hōin, then renamed Pengadilan Negeri, but otherwise the structure established during the occupation remained in force thereafter. 18 Even in those areas reoccupied by the Dutch during the revolution no attempt was made to reestablish the dual judicial organization of the prewar era, partly perhaps because of insufficient personnel.

Like the courts, the public prosecution was also unified during the occupation; the functions of the former officieren van justitie, who had served under the European procedural code, and the lowly U. $a k s a$, Indonesian prosecutors attached to the landraad, were combined in a single parquet (kensatu kyoku), organized hierarchically according to the three basic judicial levels. The police, quickly taken over by the occupation army, required less reorganization, though the distinction between city police and field police was eliminated. As in the case of the judiciary, nearly all existing 1 aws relevant to the prosecition and police were kept in force, except for certain provisions that made prosecution too difficult. When a few Indonesian judges proved reluctant to violate procedural rules in criminal actions, the military administration merely changed the laws of evidence. ${ }^{9}$ Such

16. See especially Laws no. 14 and 34, 1942 in Kan Pō (April and September 1942) and in the special number published in March $\overline{1943}$ reissuing back laws to make them more accessible. Also Tresna, Peradilan, pp. 78-81. The definitive statute on the judiciary in Sumatra did not appear until December 1943, though local regulations were promulgated before then. The major source of material on Sumatra, aside from interviews, is A. J. Piekaar, Atjeh en de oor log met Japan (The Hague and Bandung: van Hoeve, 1949), esp. pp. 263-70. There is little material on the navy-administered areas, but the pattern of change there appears to have been much like elsewhere in Indonesia.

17. The districtsgerecht (district court), regentschapsgerecht (regency court), and landraad were courts of Indonesian jurisdiction. The residentiegerecht and the Raad van Justitie (appeals) were courts primarily of European jurisdiction, but the Raad van Justitie and the Hooggerechtshof (Supreme Court) also heard appeals from the landraden. The districtsgerecht and regentschapsgerecht had been presided over by administrative officials.

18. Early in the occupation the jurisdiction of the Gun Hoin and Ken Hōin were restricted to rural areas, as the authority of the pangrè praja (regional administration) in each major city was transferred to a mayor. The landgerecht assumed the jurisdiction of these two courts. In reality, then, the judicial structure that existed during and after the revolution had already been fully established in the cities during the occupation. The landgerecht, again handled only misdemeanors. See Tresna, Peradilan, p. 79, and Kan Pō (September 9,1942 ), pp. 22-23, for an announcement of Semarang residency indicating the hierarchy of city courts with their Japanese names. Other details of jurisdictional change will be omitted here, for they are not essential to our discussion.

19. Decree of the military administrator, July 12, 1943, Kan Pö (August 1943), p. 9. Evidently simple pressure was not enough to force some judges, particularly 
amendments did not survive. Early in the revolution the occupation rules of crime and criminal procedure were rescinded in favor of the provisions of the prewar codes. The occupation left a bad taste in the mouths of professional lawyers, and the influence of the occupation on the style of Indonesian politics thereafter did not, by and large, extend to lawyers.

From the time of the occupation, courts and related institutions were staffed entirely by Indonesians. With the removal of Dutch officials, however, there were nowhere near enough trained Indonesians to fill the courts and prosecution. Many inadequately trained men started their careers as judges and prosecutors then. Lower pangrèh praja officials especially moved into the prosecution, and more were to follow during the revolution, for they did have some elementary law training. A short-course law school was established in mid-1943. Fifty out of 550 applicants were accepted in the first year for the one-year training course for judges and prosecutors; assuming some increase in enrollment thereafter, the school probably produced no more than 150 graduates, many of whom remained judges and prosecutors. The school also trained court clerks in a six-month course and other officials for the military administration. At least nine of the original teaching staff were Japanese, who taught courses related either to Japanese law or to the immediate needs of the administration. One express purpose of this school was to implant the ideas of Japanese judicial organization and process as part of the general mission civilisatrice of the occupation. ${ }^{20}$ There is little evidence that much came of it.

Outside Java judicial reorganization was more problematic. In major cities the colonial judicial structure was much the same as in Java, and courts could be unified in the same way, merely by expanding the jurisdiction of the old Landraden and Raden van Justitie to include a11 population groups other than the Japanese. But outside the large cities there also existed what must have seemed to the Japanese a confusion of customary courts, varying in makeup from area to area. ${ }^{21}$

those who had been professionals during the colonial period, to sentence accused persons without sufficient evidence, even when the military administration wanted verdicts of guilty. But once the law was amended, however much it was resented, the normative commitment of trained judges to the idea of law itself took precedence over moral objections to the new rules. There may have been a few judges who refused to serve on the occupation courts because of the ideological strain of implementing the new rules of procedure.

20. See Kan Pö (March 1943), pp. 13-14 and ibid (May 1943), pp. 23-24. Most of the students in the law course for judges and prosecutors appear to have been highschool graduates, as required. The announcement opening the course in May 1943 stated that if the goal of the course were achieved, its graduates would form a core group able to devote its energies to developing Japanese-style justice in Java.

21. In the Supomo papers there is a detailed "Note about the Judicature in Sumatra," dated December 12, 1942, written in English by Supomo himself. The purpose of the memorandum is not clear, but it may have been intended for (even requested by) the military administration of Sumatra. There were Indonesian lawyers in Sumatra, of course, and the occupation government undoubtedly referred to them, but it is possible that an overview was needed to clarify the complicated differences between the several regions. 
Unlike Java, where government justice had long prevailed, on the other islands adat courts (in both directly administered and self-governing areas) were very much a part of traditional political organization. Any tampering with these courts must therefore reflect on the authority of local leaders and quite possibly become entangled with existing patterns of social conflict in each ethnic areas.

This is what happened in Aceh, the only area outside of Java for which there is a reasonably full study of the occupation. 22 There customary courts had been fully controlled by the uleëbalang ruling class, whose authority the Dutch had strengthened against the challenge of Islam after the Atjeh War (1870-1900). While the Japanese might have been less interested in an alliance with the uleëbalang than with the Javanese priyayi elite, they fell into a close working arrangement with them anyway. ${ }^{2} 3$ Governing personnel with experience and authority were not readily available from Islamic groups, the essential opposition to older and usually nominally Islamic ruling groups nearly everywhere in the archipelago. The Japanese were not interested in the kind of social revolution that would have been required to transfer power to Islamic leaderships. On the contrary, their wartime goals in Indonesia demanded stability, which indicated, as Anderson has argued, a continuation of the essential patterns of colonial rule. Nevertheless Islamic cooperation was necessary, even after ruling classes proved willing to work with the occupation government. This was particularly so where, as in Aceh, Islamic organizations had initially supported the occupation. Consequently the Japanese played a balancing game between traditional authorities and the Islamic opposition to them; the former were maintained in power, though sometimes weakened, while the latter was given some patronage and certain organizational advantages.

In Aceh the military administration implemented a reorganization of the judiciary that in principle broke the uleëbalang hold on local courts while otherwise maintaining their administrative authority. This followed from the general principle of occupation policy that, as in Japan, executive and judicial functions should be separated. The reorganization was accomplished first of all by abolishing the distinction between directly-governed and self-governing areas and between government and native (inheemse) courts. The lower courts over which local uleëbalang had formerly presided as sole judges--the districtsgerecht and 1 andschapsgerecht--were abolished and their functions absorbed, along with those of the colonial magistrate and the residentiegerecht (for Europeans), in a new first-instance magistrate's court, the Ku-Hōin. ${ }^{24}$ A new Tihō-Hōin replaced the older musapat, a collegial customary court also controlled by the uleëbalang, the Landraad, and the Raad van Justitie in its first-instance competence. As before the war, appeals from the Tiho-Hoin went to the appellate court in Medan; like much else during the occupation, previous structural patterns remained influential, so that the occupation appeals courts were in the same cities as before. Unlike the situation in Java, however, in Aceh it proved very difficult to abolish altogether the ethnic jurisdiction of the older customary courts. The lowest court was thus

\section{Piekaar, Atjèh.}

23. See Anderson, "Japan," pp. 17-19.

24. The Ku-Hōin, actually a collegial court rather than a single magistrate, was limited in jurisdiction to minor civil and criminal cases. See Piekaar, Atjèh, pp. 264-65. 
divided into two jurisdictions, one for native Acehnese and the other for non-Acehnese. 25

This compromise of principal was accompanied by another which was equally significant. How seriously the Japanese regarded the separation of executive and judicial functions is indicated by a residential circular of October 1944 forbidding judges, without express permission of the Japanese resident, to assume other public offices. 26 The major Islamic political organization in Aceh, PUSA, whether or not it had anything to do with this circular, had much to gain from the rule and the policies that had preceded it.27 Judgeships on the Ku-Hoin were one sop that could be given to PUSA without cost to the military administration. Consequently the new magistrates' courts were occupied by large numbers of PUSA members. These were patronage appointments above all, and very few of the new judges had powerful credentials of either secular or Islamic legal learning; they were sometimes referred to contemptuously as "ulama Djepang" (Japanese ulama). ${ }^{28}$ Uleëbalang families

25. Ibid. An Islamic adviser sat on the magistrate's court in civil cases in which one or both litigants were Muslims. In mid-1944 it was provided by residential decree that when one or both parties to a dispute were Chinese, the "lieutenant" of the Chinese or his representative might sit as adviser to the court. Ibid., p. 265. The logic of colonial jurisprudence, based on an administrative conception of the plural society in which each major group comprised a self-contained unit, thus crept back into occupation practice. At the Tihō-Hōin level, however, racial and ethnic distinctions were no longer procedurally relevant.

26. Ibid., p. 267.

27. PUSA (Persatuan Ulama Seluruh Aceh, All Aceh Association of Ulama) was formally organized in 1939 and soon had a considerable following among Acehnese Muslims eager to create a new society for themselves. See ibid., passim; G. W. J. Drewes, "Indonesia: Mysticism and Activism," in G. E. von Grunebaum (ed.), Unity and Variety in Muslim Civilization (Chicago: University of Chicago Press, 1955), pp. 305-6; James T. Siege1, The Rope of God (Berkeley and Los Angeles: University of California Press, 1969), pp. 95-96 and $98 \mathrm{ff}$.

28. Piekaar reports that among the lists of Ku-Hōin judges he found the name of only one established ulama, Teungkoe Hadji Ahmad Hasballah, chairman of the court in the district of Indrapuri. Piekaar, Atjèh, p. 268. Evidently some educated urban Acehnese feared that the burgeoning Islamic judiciary might seriously consider trying to implement the rather harsh rules of Islamic criminal law. Had many of the new religious judges been steeped in Islamic learning, they might have been inclined to do so. But the issue was not in fact an important one at that time. The new judges, however, did cause confusion and uncertainty when they began to refer to new kinds of symbolic support for their decisions; for example, they occasionally would overturn prewar musapat court decisions on the grounds that they were unjust or "colonial." During the revolution the many "ulama" judges on the secular courts in Aceh were a problem for Republican justice officials in Medan. Apart from their lack of training, some local Republican leaders feared that the judges might try to transform all Acehnese secular courts into Islamic courts. The anxiety turned out to be unfounded. In fact, many who became magistrates during the occupation were eager to protect their new offices and to expand their jurisdiction over matters--inheritance, for one--controlled by Islamic courts. Rule and organizational position proved stronger than ideology. This may have helped to prevent a vast jurisdictional expansion of Islamic courts proper during the revolution. Had either secular or Islamic courts won out completely, many judges of one kind or another would, of course, have lost their jobs. 
and Acehnese intellectuals, including some devout Muslims, were evidently distressed by this development, no doubt for reasons of social class as well as political anxiety. What the above circular appeared to promise was that uleëbalang officials, dominant in local administration, would not be allowed to assert any control over the courts now surrendered to Muslims. But in fact the uleëbalang could not be kept from the judicial bench entirely. In the same circular mentioned above, according to Piekaar, a general dispensation was given with respect to Ku-Höin judges, with the result that uleëbalang did in fact serve on the courts in some areas. ${ }^{29}$ Their experience and political authority could not be and was not ignored. Yet something important had happened. In narrow institutional and broader political terms, uleëbalang control over the judicature was broken and Islamic power was accorded recognition. Acehnese cleavage politics and Japanese institutional ideology, inter alia, had split the powers of the ruling class. Later, soon after the Japanese surrender, this course of change accelerated when many uleëbalang families were slaughtered in a "social revolution" led mainly by PUSA members.

There is much less information on judicial change elsewhere outside of Java during the occupation. Everywhere the principle was established of a unified judiciary competent in disputes among all p.ulation groups, excepting Japanese nationals subject to their own $\mathrm{m} \cdot$ itary tribunals. But customary courts did not disappear everywhere, as they did in Aceh. The extent to which customary courts were cfected by the occupation, or later by the revolution, depended upon two factors: whether control over them by local ruling groups was a major issue of social conflict, and whether the opposition to them was organized. The first condition alone was usually not enough to cause the destruction of adat courts during the occupation, but the addition of the second condition during the revolution made their disappearance almost inevitable. Judging from available data for Tapanuli, Lampung, and Nusatenggara, the adat courts in those regions remained in their earlier form during the occupation even as they were incorporated into a more highly unified judicial structure. They merely assumed Japanese names. If they were raised as an issue at all, the groups opposed to them were not yet strong enough to command attention from the military administration. In several areas potential opposition groups were later mobilized by the revolution.

Noticeable changes did sometimes occur, however, even where adat courts were otherwise left alone. For one thing, as Dutch advisers disappeared, they were replaced in some cases (not all) by Japanese whose interest was 1 imited to criminal matters affecting occupation objectives. Second, Japanese insistence upon dividing executive and

29. Ibid., pp. 267-68. The influence of the ulama, legitimate or otherwise, was not permitted to enter the Tihō Hōin, located in the capital city, Kutaradja, with branches elsewhere. The Tihō Höin heard appeals from the Ku-Hōin as well as first-instance litigation. Its judges were appointed from among the few men in Aceh with any professional training at all, including some leaders who were not Acehnese by birth and who were opposed equally to the uleerbalang and political Islam. Only one of the judges was a graduate lawyer: i.e., Mr. S. M. Amin, originally from Mandailing, who had settled in Aceh and married an Acehnese woman. He played an important part in Acehnese affairs during the revolution, when he became governor of Aceh, and later still became governor of North Sumatra in the independent state. Another judge of the Tihō-Hōin was Tuanku Mahmud, whose title (Tuanku) indicates uleëbalang origins. The chairman of the court was a Japanese official. 
judicial powers occasionally influenced the structure and operation of adat courts. Traditional leaders and their staffs in the old selfgoverning areas, as well as Indonesian officials in the bureaucracy of directly-governed areas, were required in principle to leave the courts. Some may have remained judges despite this rule, either because they were highly influential or because there were no adequate replacements. A few may have chosen to give up positions in the bureaucracy in order to stay on the courts. The new chairmen of adat courts were generally appointed from among former court clerks (in the Landraden, for example) and the like with some judicial experience. Where this was the case, as in Tapanuli, it proved easier during the revolution to eliminate adat courts altogether, because judicial leadership was no longer closely linked to political, social, and administrative leadership. Elsewhere, as in South Sumatra, where the local bureaucracy either retained its influence in the courts or had it restored to them when the Dutch returned, the adat courts were able to hold out for a few years longer.

The unification of courts during the occupation was by and large limited to the principal of no racial differentiation of jurisdictions. Unification in the wider sense of a national judicial system was not considered at all, for the reason that wartime Indonesia was divided into three parts. That Japanese policy may have assumed a more permanent arrangement of this sort is indicated, perhaps, by a decision in 1944 to do away with the Supreme Court that had been created in Jakarta early in the occupation, probably in imitation of the colonial judicial system. ${ }^{30}$ This Supreme Court thereafter became the appeals court for West Java. Each of the three Javanese provinces then had an independent appellate court that served as the highest instance of appeal, other than the occupation command, and was administratively responsible for the lower courts in its jurisdiction. During the revolution the lack of a national Supreme Court was quickly rectified.

The revolution also brought the start of an effort to unify all the courts of Indonesia into a single national judicial system, an effort finally completed for secular courts only in 1960. The occupation contributed to this horizontal unification by weakning the ties between local traditional authority and judicial institutions in several regions of the country. But for the process to be completed, local orientations had to be transformed in some measure into national ones.

The Revolution

The revolution provided such a transformation. In some regions the initial intensity of the upheaval was so great that reluctant local elites were eliminated and national institutions adopted with enormous speed and ease. Elsewhere the intensity was less, but sufficient to provide some momentum to the process of unification. The key to such change was a rapid mobilization of society during the revolution, a mobilization for which national symbols were available and useful to

30. Law of January 14, 1944, cited in the clarification to Law $7 / 1947$ of the Republic of Indonesia, on the organization of the Supreme Court and the Chief Public Prosecution, in Koesnodiprodjo, Himpunan Undang2, Peraturan2, Penetapan2 Pemerintah Republik Indonesia (Jakarta: Seno, 1951), vol. 1947, p. 17. 
local change-oriented groups. Institutional unification probably would have begun without this revolutionary mobilization, as it has in other countries where no national revolutions occurred, but it would have been incomparably slower and different in character.

Following the Japanese surrender and the Proclamation of Independence in August 1945, national unity was a major concern of Republican leaders, but little thought was given to institutional innovation. For most national leaders, Sukarno and Hatta included, the revolution was first of all to gain independence from the Dutch. Men talked of adical political, social, and economic change that would follow independence, and these ideals showed up in policy statements that could not be implemented either during or after the revolution. But there was hardly any strategy of social revolution or even social change. The national elite that emerged from the occupation was largely the same one that had dominated Indonesian politics in the colony, though some new mobile elements were introduced by the occupation and, later, the revolution. For the most part, it was not a socially radical leadership group, and its revolutionary goals were limited. Consequently, when issues were raised about institutional policy, most leaders tended to fall back on the familiar. The constitution of 1945 was reminiscent of the institutions of colonial Indonesia. All laws in force at the time of the Proclamation of Independence were retained. Japanese criminal provisions were rescinded in favor of the older criminal code, to which a few minor amendments were made. But occupation innovations in judicial organization were kept.

The retention of old laws and institutions allowed a procedural integration of sorts until new principles of legitimacy could be worked out.31 In effect, it permitted leaders to assume that the essential structure of a state existed. But more was involved, as becomes evident when one thinks of the alternative possibility of obliterating colonial law and legal forms. Like many other new states, Indonesia possessed no fully articulated ideology backed up by a powerful political organization. Without these, abolishing the old law could only mean a symbolic vacuum, into which chaos must rush. Or so it probab1y seemed. In addition, the old legal forms were kept because there were interests vested in them among those about to inherit the state. Professional skills were tied up with them, and men were used to them, often knowing no others. Innovations seemed impracticable and threatening. In the constitutional discussions of mid-1945, Muhammad Yamin, a lawyer who had not practiced law very much but who had become a leading nationalist spokesman, was one of few to propose any imaginative institutional change. With respect to the judiciary, he argued that the Supreme Court should have full powers of review over all legislation. But Professor Supomo, in charge of drafting and defending the new constitution, typically replied that Indonesian lawyers were not familiar with the legal systems (such as that of the United States) from which Yamin took his examples. Supomo's argument won. 32

There were other reasons for keeping extant law and institutional forms that should be explored before returning to the problem of judi-

31. David Apter, The Politics of Modernization (Chicago and London: University of Chicago Press, 1965), p. 271, note 4.

32. Muh. Yamin, Naskah-Naskah Undang-Undang Dasar 1945 (Jakarta: Jajasan Prapantja, 1959), in the minutes of the Committee for the Preparation of Independence, session of July 15, 1945, pp. 336-42. 
cial unification. Retaining the old legal system more or less intact was not merely a matter of convenience. Nor was it simply because no one had any new ideas. In this new state there were contending groups and ideologies, each in a sense having an alternative political and legal system to offer. During the colonial period Islam and the various adat realms had been kept apart and at bay, while colonial secular law itself offered a reasonably neutral medium of interaction controlled by an outside authority. Colonial law, Islamic law, and adat 1 aw were distinguished not only by their substantive rules but by their quite different sources of legitimacy. Islamic law is sanctioned by the Almighty, adat law by the diverse societies it separately serves, and the colonial law by the secular colonial state. Of the three, Islam and adat were historically antithetical and both unacceptable to national leaders impelled by the twin desires for national unity and "modernization." Islam particularly had always been a serious political and cultural threat to the non-Islamically inspired elite in power since 1945. When necessary, this elite--largely Javanese priyayi and politically like-minded leaders from elsewhere in the country--would use the symbol of local adat against the challenge of Islam. Whatever its other symbolic disadvantages for national leaders, the old colonial legal system did offer two extremely important advantages. One was a national conceptual scheme: for Indonesian leaders who had accepted the idea of a state comprising the whole of the former colony, the colonial law provided an available and appropriate framework. The other was a symbolically secular neutrality between conflicting religious and social groups, but one that also kept the existing dominant elite in control of national institutions.

Without a revolution, these same conceptions promoted by colonial law would undoubtedly have slowed the process of institutional unification, for they would have worked to the advantage of local elites in their inevitable struggle with national authority. As it happened, revolutionary events led to the destruction of old local authority in several areas, rendering the symbolic support of the legal system meaningless.

It was argued above that national leaders were not bent upon radical political and social innovation. But they were concerned with the modernization of Indonesia, an idea which was variously interpreted, but which generally meant becoming economically and politically rather more like the states of Europe. Moreover, the start of the revolution against the returning Dutch brought with it a new strain of egalitarianism, which eventually declined but at the time had considerable influence. Furthermore, national leaders in the revolutionary capital of Yogyakarta were committed to unifying the whole country, which meant that state institutions had to be extended outwards and established everywhere in Indonesia.

In Java this was not really much of a problem. The essential administrative machinery of the island had long been integrated under Dutch rule. In the case of the courts, much of what had to be done by way of unification had already been taken care of during the occupation. Only the kraton courts remained--these had actually been revived by the colonial administration to manage internal disputes of the royal houses of Yogyakarta and Surakarta. They were easily abolished by the republican government in mid-1947, a matter we will discuss again shortly.

It was outside Java where problems of unification were most compelling, and over these the government in Yogyakarta had almost no 
control. Representatives of the Republic of Indonesia in Sumatra, Sulawesi, Kalimantan, and elsewhere were often self-selected, with post hoc appointments from Yogyakarta. ${ }^{3}$ Communications were at best irregular. Nevertheless, unifying tendencies were evident in a kind of two-way process. On the one hand the revolutionary government desired to expand its authority outwards via institutions considered national. On the other hand, in some places local institutions were overthrown and replaced by men who for any number of local political and revolutionary reasons sought to relate themselves to national symbols.

A striking instance of the uses and complications of social mobilization for the expansion of national institutions was the final demolition of adat courts and the adoption of national courts in North Sumatra early in the revolution.

Political conditions throughout Sumatra were in confusion after the Japanese surrender. Not only were Republican officials in the major cities unable to exercise real control over the population, but there was little concentrated authority anywhere at a11.34 In December 1945 and January 1946 Islamic groups in Aceh rose against the uleëbalang families, eliminating about half the petty rulers in the region, according to Kahin. But the bloody action was not carried out in the first place under an Islamic banner. Rather, participants were "freedom fighters" in a "people's revolution," and were supported by the local Republican committee. ${ }^{35}$ Had the uleëbalang intended to restore their old courts, which had not been popular before the war, the uprising naturally prevented it. Even more questionable "ulama" moved into the lowest courts carried over from the occupation, much to the dismay of justice officials in Medan. ${ }^{36}$ But many of these judges were

33. On the revolutionary period, see especially George McT. Kahin, Nationalism and Revolution in Indonesia (Ithaca: Cornell University Press, 1952), and Benedict R. O'G. Anderson, Java in a Time of Revolution (Ithaca: Cornell University Press, 1972).

34. See Kahin, Nationalism, pp. $178 \mathrm{ff}$., and H. Mohammed Said, "What was the 'Social Revolution of $1946^{\prime}$ in East Sumatra?" translated from the original article serialized in the Jakarta daily Merdeka (February and March 1972) by Benedict Anderson and Toenggoel Siagian, Indonesia, No. 15 (April 1973), pp. 145-86.

35. Ibid., p. 169.

36. By this time the representative of the national Ministry of Justice in North Sumatra was Mr. Hanafiah, Acehnese in origin, who had been director of justice in Medan during the occupation. Much of my information about revolutionary events in North Sumatra comes from him and others whom I interviewed in Medan during April 1960. Hanafiah went to Aceh after the uprising there to find nearly all courts, secular and Islamic alike, presided over by a wide variety of ulama. Only the former Tihō Hōin, which was to become the basis for new national courts, still had judges with some professional training. When the Japanese left Aceh, the ulama judges on the secular courts insisted that they would apply Acehnese law to everyone. Concretely this meant, for example, that rather harsh rules with respect to such matters as adultery, broadly interpreted in some Acehnese circles, would be imposed on all residents. This might have caused a great deal of trouble. As a way out of the problem--one example of many imaginative solutions to difficulties arising from the establishment of new institutions--Hanafiah suggested that when harsh criminal sentences were 
eager for official recognition, so that few difficulties arose later in transforming the existing courts into national first-instance courts (Pengadilan Negeri).

In early March 1946 a similarly brutal uprising occurred in East Sumatra against the several sultanates that had reigned in the area. These sultans had little identification with many local inhabitants of East Sumatra, particularly the Karo and Simelungun Batak inland from the Malay areas on the coast, and had been closely allied with the Dutch. In order to head off in East Sumatra what had happened in Aceh, the sultans had agreed, at a February 1946 meeting with Republican officials, to turn over their powers to the new national government. But violence broke out anyway, promoted by rumors that the sultans planned to help the Dutch return. The killing, burning, and looting are still remember with some horror, as well as enthusiasm, in East Sumatra. The Nationalist (PNI) and Communist (PKI) parties were involved in the uprising, as were other dissatisfied groups, influenced perhaps by the recent events in Aceh, but there is no point in discussing the complex politics of the affair here; H. Mohammed Said's interesting article is enlightening on the subject. For our purposes what is important is that the local causes of the uprising were articulated in terms of new national and revolutionary symbols. In East Sumatra, as in Aceh, the adat (but not the Islamic) courts of the sultanates had already been absorbed by the unified judiciary of the occupation. But the destruction of the sultanates, which eliminated forever the authoritative basis of older customary institutions, and the revolutionary appeal to national symbols, made it possible to establish national institutions with relative ease.

At the same time, as the fervor beginning with the "social revolution" against the sultanates spread, the Karo Batak area to the west broke out in a spirit of revolutionary democracy. Whatever courts existed there were eliminated and local revolutionary groups demanded that henceforth the people should choose their own judges. New courts were actually set up throughout the area--over 100 of them according to one source--with judges and prosecutors selected by local revolutionary leaders. These leaders, and the judges they appointed, were by all accounts new political elements, cast up by the revolution itself. Sometime in mid-1946 a group of the new judges came to Medan to meet with Hanafiah, the representative of the national Ministry of Justice. They demanded from his official appointments as government judges. On the advice of Minister of Justice Susanto, who happened to be in Medan at the time, Hanafiah offered appointments to about half of these men, none of them trained in 1aw. About twenty actually received appointments before the Dutch returned to assume control over the area.37 It might have been politically, and possibly physically, dangerous to refuse their demands, but the situation was altogether favorable for the expansion of national institutional symbols. The "people's judges"

appealed to the court in Kutaradja, they should be sent to the appellate court in Medan. The appellate court would then send word that the cases were under consideration and the accused persons should be released pending final decision. Thereafter the case documents would simply be put aside and forgotten.

37. After the transfer of sovereignty, these revolutionary judges demanded wages for the years they spent in the forests following the Dutch return. Political discretion finally dictated that they would be paid, and some were given jobs as clerks and the like in first-instance courts. 
wanted official legitimacy, and Hanafiah reportedly asked them whether they were Karo judges or judges of the Republic of Indonesia. Repub1ic of Indonesia, they replied, and Hanafiah could then follow with an admonition that they must therefore apply the law of the Republic, the logic of which seemed clear enough. The same approach was used with the ulama judges in Aceh. ${ }^{38}$

Similar but more moderate developments took place in Tapanuli. Here there was no "social revolution" of the sort that occurred in Aceh and East Sumatra, mainly because no distinct and insulated ruling class, like the uleëbalang and coastal Malay sultans, existed among the Christian Toba of the area. The petty raja of Tapanuli were bound to the population by agnatic kinship ties, which limited the stratificatory gap between rulers and ruled and militated against the evolution of a rigid class identification among the governing elite. In the nineteenth century, during the pidari [paderi] period of inter-village warfare, the originally kinship-organized society had begun to assume territorial characteristics at the village (huta) level. Dutch reorganizations carried this process of change much further. ${ }^{39}$ Thus the customary courts established there by the colonial government, particularly in the $1930^{\prime} \mathrm{s}$, had territorial jurisdictions. They consisted first of a conciliation body in the village (or kampung, a Dutch innovation, consisting of several huta), a rapat kecil (small sessions) headed by the kepala negeri (district chief), and a rapat besar (superior sessions) chaired by the local Dutch Controleur with several kepala negeri as member judges. The authority of village level radja and district chiefs had begun to decline, according to Vergouwen, under the impact of a growing Dutch-sponsored Batak bureaucracy with a wide variety of welfare and other functions. It was these administrators who first replaced Dutch officials on the highest adat courts incorporated into the occupation judiciary, but then were forced to leave again. Many raja and kepala negeri, however, had remained on the courts throughout the occupation, and it is likely that when the occupation ended they assumed that their control of the courts would continue. But some overflow of the revolutionary activity in East Sumatra entered Tapanuli, partly by way of para-military bands (Zasykar) that had moved inland from the coast. Apparently these groups were quickly bottled up, but they contributed to the growing tension of politics in Tapanuli. Revolutionary conditions encouraged challenges to the authority of the old leadership group of the area. Not much blood was spilled, but the raja and kepala negeri began to move aside before

38. In fact, of course, most of the new judges had little or no knowledge of formal $1 \mathrm{aw}$, and when they were told what it was with respect to various matters they sometimes rebelled against it, insisting that local law--the adat, or "people's $1 \mathrm{aw}$ "--would be applied. For example, when the evidentiary requirements of the procedural code (Rechtsreglement Buitengewesten) concerning accusations of adultery were explained to judges in Aceh, they proposed to create a new law; it was finally agreed that that would not be possible in the unitary state, so they simply ignored the formal rules. But regardless of the rules applied in court, decisions were made in the name of the new state, creating symbolic ties.

39. See J. C. Vergouwen, The Social Organization and Customary Law of the Toba Batak of Northern Sumatra (The Hague: Nijhoff, 1964), pp. $127 \mathrm{ff.,}$ and Clark E. Cunningham, The Postwar Migration of the Toba-Bataks to East Sumatra (New Haven: Yale University, Southeast Asia Studies, Cultural Report Series, 1958), pp. 33-39 for a discussion of past and present village organization. 
the pressure of newly-organized groups that identified themselves with the revolution and its egalitarian appeals. The end result was that the old adat courts, from the village level upwards, lost whatever traditional basis of authority remained to them. The courts did continue for a while during the revolution, frequently with new revolutionary judges. But for legitimacy these judges could hardly appeal to tradition or to kinship. Such authority as they had depended upon an appeal to the revolution, and through the revolution to the new national Republic. The way had thus been cleared for the establishment of national courts.

In the meantime, during 1946, Republican administrative officials and the few national judges who had been appointed in North Sumatra were eager to hasten the abolition of the old customary courts.40 In Tapanuli, for example, the title of government court (Pengadilan Negeri) was imposed upon the rapat besar even before these adat courts had been altered in any other way. Nearly all these officials of the revolutionary government belonged to the small but growing group of educated urban professionals for whom the old rural culture and traditiona1 institutions were neither imperative nor marvelous; on the contrary, they were "primitive." During the late colonial period some of these men had already expressed their disdain, as professional lawyers, for the adat courts, whose judges, they argued, were uncontrolled and arbitrary. They tended to favor legal "modernization." It was these men who rapidly identified with the revolution and with the new state, while many traditional leaders were not noticeably enthusiastic about either. There was, in effect, an implicit struggle between urban and rural leaderships, with all the attached connotations of "modern" versus "traditional" and so on.

In any event, in late 1946 Hanafiah convened a conference at Pematang Siantar, not far from Medan, of national government judges from al1 over Sumatra, partly in order to get some picture of what was happening. The conference decided inter alia that customary courts should be abolished everywhere and replaced by new national courts. This became Republican policy for all of Sumatra until the Dutch returned in mid-1947. Where the Dutch did not re-establish control, as in Aceh and Tapanuli, the customary courts remained abolished. This was also true of East Sumatra, where no basis existed for reinstating the old customary courts after the sultanates had been crushed. Instead, in East Sumatra as in other areas of the country, the returning Dutch administration created unified courts for all population groups ( 2 andgerecht nieuwe stijl). Whether or not there were other considerations behind this policy, it was probably most convenient for the Dutch to establish unified courts, both because there were not enough personnel to staff the plethora of courts that had existed before the war and because reconstructing a plural judicial system might have added one more issue of conflict. In South Sumatra and elsewhere, however, where customary courts had not yet been eliminated entirely before the Dutch returned, the Dutch attempted to strengthen them, which meant strengthening existing local ruling groups. The administration even created a new adat appeals instance (rapat tinggi) in South Sumatra that remained in operation until 1960.41

40. These included not only Mr. Hanafiah in Medan, but also Mr. Silitonga, a Toba Batak, who became Ministry of Justice representative for North Tapanuli, and judges Rem and Siregar in the city of Sibolga on the west coast of Tapanuli. All were trained in law.

41. No detailed attention will be paid here to the judicial arrangements of Dutchoccupied territory during the revolution; they are not essential to our 
To return to Yogyakarta, the national Republican government did little with respect to judicial organization in 1946 . Only in 1947 and 1948 did justice officials begin to order their thoughts about national judicial institutions. In February 1947 they promulgated a new law on the organization and powers of the Supreme Court (Mahkamah Agung) and the Chief Public Prosecution (Kedjaksaan Agung). 42 The clarification of the new law made it absolutely clear that the government intended to construct a unified court system as part of the effort to unify the state. Several months later, in August 1947, a second law abolished the customary courts of the former self-governing areas of Java and Sumatra.43 Justice officials in Sumatra had wanted such a law, to give national legitimacy to what had already happened in Aceh and East Sumatra. In fact, they wanted a new law doing away with adat courts throughout Indonesia, not only the so-called selfgoverning areas of Java and Sumatra. This would have validated the al1-Sumatra policy established by the Pematang Siantar conference and extended it to all of Indonesia. But while national leaders had no qualms about challenging old royalty, obviously in decline anyway and running against the grain of revolutionary egalitarian symbols, political conditions in other parts of the country were less clear and therefore more delicate. Even the self-governing areas of Kalimantan, Sulawesi, and Nusatenggara were left alone for the time being. 44

analysis. In general, however, the Dutch took over the unifying innovations of both the occupation and the Republic of Indonesia. In the federal states created by the Dutch administration, judicial organization followed a unified model, though some customary courts were left in operation and protected. For a discussion of the formal aspects of judicial change in Dutch-controlled areas, see A. Arthur Schiller, The Formation of Federal Indonesia 1945-1949 (The Hague and Bandung: van Hoeve, 1955), pp. 308-36, and Tresna, Peradilan, pp. 82-85. In South Sumatra during the occupation a kind of rapat tinggi also existed, but it was the Dutch model that was retained after 1950 . It will be discussed further below.

42. Undang-Undang (Law) $7 / 1947$, February 27,1947 , in Koesnodiprodjo, Himpunan, 1947, pp. 14-18. The first article of the law, indicating the existence of the Mahkamah Agung and Kedjaksaan Agung, was declared retroactive to August 17, 1945, the date of the Proclamation of Independence. The law was exceedingly brief, with only six articles on the authority and responsibilities of the two institutions. The constitution of 1945 had provided for a Supreme Court, but not the prosecution, though both bodies were in existence almost from the beginning.

43. Undang-Undang 23/1947, August 29, 1947, in Koesnodiprodjo, Himpunan, 1947, pp. 88-91. The clarification of the statute indicated forcefully that there was no need to ask the permission of the princes (of Java) to abolish their courts, but that they were consulted anyway. There were, of course, no such consultations in Sumatra. Javanese Republican officials felt rather closer to and had more respect for Javanese royalty than did outer island Republicans for their local aristocracies. The internal court of the minor royal line in Yogyakarta, the Pakualaman, had already been abolished in 1908, at the request of the reigning prince, so only the remaining three--two in Surakarta and one in Yogyakarta --had to be got rid of.

44. It is difficult to obtain material on judicial developments in Kalimantan, Sulawesi, and other islands during the revolution, but for South Sulawesi at least there is some evidence that local rulers who did not join the revolution were pushed aside while others voluntarily gave up their control over customary courts. 
Republican officials in the revolutionary capital were themselves interested in eliminating the internal courts of the princely states of Yogyakarta and Surakarta. Lawyers in the Ministry of Justice regarded the royal judiciaries as anachronistic in a modern state. But in addition the Surakarta princes (the Susuhunan and the Mangkunegoro) were politically suspect in Republican circles, and in 1946 the Susuhunan had become the object of political attack by young Republican soldiers. 45 The Surakarta princes were soon forced to surrender nearly all of their authority to the national government. The Sultan of Yogyakarta (Hamengkubuwono IX), however, had enthusiastically joined the cause of independence and agreed that the royal customary courts should be done away with.

The clarification of the law that abolished adat courts in Java and Sumatra reaffirmed the policy of unification in very strong terms. Referring to the colonial distinction between government justice and that of the self-governing areas, the clarification stated:

The Government of the Republic of Indonesia is not at all merely the successor of the Netherlands-Indies Administration. . . . The Republic of Indonesia is a State which we, the whole Indonesian people, have established together as a united and sovereign State. Its Government consists of our own people. . . . The justice established throughout our State for all citizens (including those living in special regions [i.e., the former self-governing areas]) is justice "in the name of the Republic of Indonesia." Nor is that justice limited by the existence of various regions, and it would not be appropriate to divide it up into so many "sferen van rechtspraak" [areas of independent administration of justice, as in the colony]. From the beginning it has been the responsibility of the central Government to administer justice, as intended by article 24 of the Constitution.

These were the express ideals of the independence movement, now stated specifically with respect to judicial organization. The urge to national unity was reflected similarly in nearly every other kind of public organizational and symbolic activity from the time of the revolution.

The next major step toward judicial unification during the revo1ution was the promulgation of a new statute on judicial organization in June 1948.46 It never went into effect because the Dutch army took Yogyakarta, and new laws were later drafted after the transfer of sovereignty. But the basic ideas (and aspirations of 1 aw leaders) behind a national court system had been worked out by this time and were incorporated into the new law. The unification of courts achieved by the occupation was retained, but the judicial hierarchy was simplified. The colonial districtsgerecht and regentschapsgerecht in Java, and similar low-level courts elsewhere that the Japanese had retained, were eliminated. This made permanent the Japanese policy of separating executive and judicial functions by merely abolishing those courts traditionally controlled by the bureaucracy. It was easily accomplished because the pangrèh praja, now renamed pamong praja, the

45. See Kahin, Nationalism, pp. $185 \mathrm{ff}$. , and Anderson, Java, pp. $351 \mathrm{ff}$.

46. Undang-Undang 19/1948, June 8, 1948, in Koesnodiprodjo, Himpunan, 1958, pp. $62-74$. 
regional bureaucratic arm of the central government, had begun to nedken during the occupation and its decline continued during the revolution. Only three judicial levels were recognized in the new law: the Pengadilan Negeri (first instance), Pengadilan Tinggi (appeals), and Mahkamah Agung (Supreme Court). These have remained to the present.

The growing commitment of Ministry of Justice lawyers to complete unification of the judicial system is indicated by several other articles of the 1948 law that deserve brief mention. 47 No customary courts were provided for in the law, implying their abolition where that had not already been achieved by previous legislation. ${ }^{48}$ Ministry of Justice officials no longer felt so cautious when planning the future state. But the implicit abolition of adat courts was qualified (in article 10) by the provision that where the "living law of society" indicates that certain conflicts and crimes should be heard and decided by those who exercise authority in that society, these authorities should continue to decide such cases. The vague language is significant, indicating a number of worries beginning to burden justice officials and also some emerging political conflicts. For one thing, Ministry of Justice leaders recognized that actually abolishing adat courts, or weakening the local ruling groups that controlled them, might be more difficult than simply commanding it; so they had to provide for such legal process without, however, granting it any more authority than was absolutely necessary. By refusing to use the term "adat courts," the drafters of the law no doubt hoped to diminish their legitimacy and render them that much less permanent. In order to create as many avenues as possible away from local authorities towards national institutions, the second paragraph of the same article provided that nothing said in the first paragraph should prevent litigants from bringing their cases to regular government courts, before or after a decision had been rendered by local authorities. National justice officials were developing a kind of gradualist strategy, along with more abrupt approaches, for dealing with local power outside of Java.49

47. The Minister of Justice during most of the years of revolution was Mr. Susanto Tirtoprodjo, a rather elderly official known for his administrative abilities. Years later, after a time as a diplomat, he became chairman of the Institute for the Development of National Law. He was also the elder brother of Wirjono Prodjodikoro, second Chairman of the Supreme Court. Professor Supomo had been the first Minister of Justice after the Proclamation of Independence, but soon was dropped from the cabinet by Prime Minister Sjahrir in favor of Mr. Suwandi, a respected notary associated with Sjahrir's own political and intellectual circle. Susanto succeeded Suwandi. Continuity in the ministry, as well as considerable drive, was lent by Mr. Besar Martokusumo, secretary-general of the ministry until 1959. The first Indonesian private advocate, and a successful one, $\mathrm{Mr}$. Besar was highly respected by professional lawyers, for whom he was an important link with the ministry. The top leadership of the Ministry of Justice has been largely Javanese since the revolution, more so perhaps than most ministries, because of the domination of the law professions by Javanese.

48. The 1948 law recognized three spheres of government justice: general, administrative, and military. Of these the statute provided only for general justice, which was to consist of a single judicial hierarchy. This excluded not only adat but also Islamic courts. See articles 6 and 7 of Law 19/1948.

49. For Ministry of Justice officials the primary concern of unification was the outer islands, which Javanese leaders tended to regard with anxious disdain. Among other matters, they feared that government judges outside of Java might 
A second problem was becoming even more compelling and certainly more complex. The "living law of society" formula, while it seemed on the surface to involve only the problem of local adat, actually masked an increasingly tense issue between those who controlled the new national government and the forces of Islam. Islamic leaders favored the "living law" concept because it would, they assumed, permit recognition of the extent to which people actually followed Islamic law rather than ancient local customary rules. Colonial adat-law doctrine held that Islamic law rules could be recognized only to the extent that they had been absorbed by and had become part of local adat law, which favored local traditional authority against Islamic challenges. "Living 1 aw" could be either Islamic or adat. But justice officials-largely Javanese priyayi, opposed to political Islam and committed to concepts of secular law and the secular state--were also willing to live with the "living law" notion. It offered them two kinds of advantages. On the one hand, it opened up conceptually the perspective on local customary law and institutions, rendering them less impervious to change and outside influence. On the other hand, "living law" could be used as well as adat as an anti-Islamic symbol. It left an opening - - one that was in fact used--for a tacit alliance between national and traditional local power against Islam. While the national government did what it could to extend its own influence at the expense of local authority, at the same time national institutions, the judiciary for one, took over the struggle of local adat against Islam.

Islam was powerful nationally, while by its nature adat could be powerful only locally. Thus it was easier to abolish adat courts than slamic courts. But the Ministry of Justice tried. In the 1948 law a distinct sphere of Islamic justice was not mentioned at all. Rather the statute provided that in cases between Islamic litigants over issues to which Islamic law applied, the first instance and appellate courts would sit with a Muslim chairman and two judges expert in Islamic 1 aw (articles 35 and 45). It is unlikely that Ministry of Justice officials consulted with leaders of the Ministry of Religion or Islamic groups about this. Undoubtedly they would have rejected it on the spot. As it was, the effort failed anyway, and later even more moderate attempts to absorb the Islamic judiciary were ignored by the Islamic leadership. 50

Judicial Unification in the Independent State

With independence, national leaders in Jakarta intensified the effort to extend the jurisdiction of national institutions outwards over the whole of Indonesia. But soon the ideological advantages of the revolution for institutional integration diminished. Local interests emerged more vigorously and linked up with currents of national

be of low quality or altogether untrained, a legitimate concern given that few Indonesians were trained in law and most of them lived in Javanese cities. Article 70 of the 1948 statute provided that on the advice of the Supreme Court (Mahkamah Agung) the Minister of Justice could require Pengadilan Negeri outside of Java-Madura to send all their decisions to appropriate appeals courts for reexamination and possibly retrial. Later statutes did not distinguish in this way between Javanese and non-Javanese jurisdictions.

50. See Lev, Islamic Courts in Indonesia, pp. $62 \mathrm{ff}$. 
political conflict to make the process of unification more difficult. Herc and in the last part of this article I want to discuss the final elimination of adat courts and one early attempt to restore them. The data I have comes mainly from South and North Sumatra.

The final stages of judicial unification occurred after the transfer of sovereignty, on a theme begun during the revolution. By then the ideology of law leaders had come a long way from the colonial system. Unification now meant centralization, the expansion of national institutions, in which many professional lawyers were already involved in one way or another. Adat law, which colonial legal training had emphasized, now became a bit suspect. It still carried the favorable implication of something specifically Indonesian, and it still was useful in holding off the claims of Islam. But it now also became symbolic of local autonomy and, as always among urban lawyers, seemed "backward," unmodern. Even Professor Supomo, a confident proponent of adat 1 aw during the 1930's, began to argue that Indonesia needed modern codes and institutions. ${ }^{1}$ With only a few exceptions, lawyers were now committed to creating a "modern" centralized state, in which there was little room for local legal initiative.

The remaining customary courts were abolished in two waves, one soon after the Dutch left and the other within a decade. The first wave of activity was part of the more general effort to create a unitary state out of the federal system left behind by the Dutch, and it benefited from the still powerful momentum of revolutionary symbolism. The federal arrangement did not last long. Within a year of the transfer of sovereignty (December 27, 1949) the several constituent states joined the Republic of Indonesia to form a unitary state.52 It was a period of national fervor that was not sustained in later years. At this time and shortly afterward justice officials began to put the national judicial system in order. In 1950 and 1951 two basic statutes were promulgated which remained in force until the mid-1960's: one on the supreme Court and the other on the organization and procedure of

51. See Supomo, "Hukum Adat dikemudian Hari berhubung dengan Pembinaan Negara Indonesia," Madjallah Hukum, 1952, No. 4-5. The English version of this paper is in Philip Thayer (ed.), Southeast Asia in the Coming World (Baltimore: Johns Hopkins Press, 1953), pp. 217-35. Something of the romance of adat law was still evident in Supomo's discussion, but his concern had shifted from province to center. Similarly, in a paper on judicial organization in federal Indonesia prepared for the Round Table Conference in 1949, Supomo, who had opposed Yamin's use of American legal models in 1945, now suggested that the federal Supreme Court be given powers of review over all federal and state legislation. Why this is significant--since the federal scheme failed anyway--is that it grew out of new assumptions favoring central authority against local autonomy.

52. See Kahin, Nationalism, pp. 446-69. On the legal institutions of the federal system, see Schiller, The Formation, pp. $330 \mathrm{ff.}$, and Tresna, Peradilan, pp. 84-85. The federal constitution was replaced with a new provisional constitution (1950) so quickly drafted that some problems arose later with respect to formal institutions and procedures. Few leaders, at least in Java, expected the federal state to last long, and much of the preparatory work for independence was done on this assumption. The Ministry of Justice of the federal government, led by Prof. Supomo, and that of the Republic of Indonesia, headed temporarily by A. G. Pringgodigdo, cooperated very closely. The Republican Supreme Court was transferred to Jakarta as the federal Supreme Court, again on the assumption that only one Supreme Court would be needed. 
civil courts. 53 The second is the more important for our discussion. It provided for a fully unified judiciary and the gradual abolition of al1 customary courts, both in the former self-governing and directly governed areas.54 The work of the occupation and revolution were thus consolidated by the law leaders of the independent state, but the revolutionary momentum of unification, particularly with respect to eliminating adat courts, was moderated. The drafters of the statute were uncomfortable with the need to go slowly in abolishing all adat courts. But there seemed 1ittle choice. For one thing, local resistance had set in. For another, administrative caution in Jakarta warned that there were not enough government judges to go around. As it was, many inadequately trained personnel had been appointed as judges in Java, let alone the other islands. One consequence of permitting adat courts to continue until replaced, however--and of some uncertainty about what still constituted valid customary 1 aw in the several regions--was that the ?ew law had to stipulate that customary crimes and punishments woula not yet be abolished. 55 As for Islamic courts, officials in the

33. Undang-Undang $1 / 1950$ tentang susunan, kekuasaan dan jalan-pengadilan Mahkamah Agung Indonesia, promulgated on May 9, 1950, still during the federal period. Undang-Undang Darurat 1/1951 tentang tindakan2 sementara untuk menyelenggarakan kesatuan susunan, kakuasaan dan acara Pengadilan-pengadilan Sipil. Both statutes are in J. H. Scheers. V. F. M. Hartog, and W. Sidabutar, Susunan Pengadilan dalam Negara Republik Indonesia (Jakarta: Pustaka Rakyat, 1952). The 1951 law was not discussed by Parliament, though it was supposed to have been; other issues took precedence and Parliament never got round to it.

54. Thus the statutory underpinnings of the adat law policy of the late colonial period--the laws of 1932 and 1938, which provided for reorganizing and strenghening adat courts, and the law of 1938 on self-governing areas--were done away with, as in effect was much of the work of van Vollenhoven and ter Haar. Article 1 of the new law specifically abolished the appeals courts and landgerechten (new style) established by the Dutch administration during the revolution, all the old landgerechten, regentschapsgerechten, districtsgerechten, magistrates courts, and similar judicial bodies over all of Indonesia. The self-governing areas whose courts were specifically abolished included those of the former state (within the federal system) of East Sumatra, the former residency of West Kalimantan, and the former state of East Indonesia. Aceh was unaccountably not mentioned, though the swapradja (self-governing) courts there and in East Sumatra had been abolished at the same time in 1948; it may have been an oversight, a frequent occurrence in the legislation of this period, or it may have been because of some worry in Jakarta about conditions in Aceh. As in the law of 1948, only the Pengadilan Negeri, Pengadilan Tinggi, and Mahkamah Agung remained as government courts. The abolition of adat courts did not apply to the so-called hakim perdamaian (conciliation judges) in villages, provided for in article 3a of the colonial statute on judicial organization (Rechterlijke Organisatie). But this provision, and its approval in the 1951 law, were a bit whimsical, for few legal experts knew exactly where and how such functions were exercised in the villages. It probably seemed best not to deny, even formally, the right of villages to manage their own affairs at least to that degree.

55. See the clarification of 1 aw $1 / 1951$ in Scheers, Hartor, and Sidabutar, Susunan, pp. 102-4. Although adat crimes were still recognized, it was provided (article 3b) that they would be assimilated, in effect, to the criminal code; where an adat crime had no analogue in the criminal code, it would be punished by no more than three months jail or a 500-rupiah fine, instead of the adat punishment, if the accused did not adhere to the adat rule in question and the judge thought the above punishment proper. But the judge could also render a sentence of up 
Ministry of Justice were more circumspect than they had been in 1948 . The 1951 law recognized the separate existence of Islamic courts, while pointing out their limitations, but suggested hopefully that the Government would consult with Parliament on the question whether issues subject to Islamic law should not be transferred to the Pengadilan Negeri. 56

Within the next two years the Ministry of Justice worked at replacing customary courts with Pengadilan Negeri in Bali, Lombok, and Sulawesi, and then more gradually in Kalimantan, the islands east of Lombok, and Bengkulu and Rejang in Sumatra. In some places, the shortage of judges made it impossible to establish government courts immediately; in North Sulawesi, for example, adat courts apparently continued for a few years after it became quite clear that relatively few obstacles prevented their elimination. 57 The procedure for getting rid of customary courts was reasonably simple, though it required some delicacy and sensitivity to local politics. Mr. Besar, secretarygeneral of the Ministry of Justice, traveled from area to area assessing whether elimination of customary courts would cause tension and whether there were judges to staff new government courts. In Bali and Sulawesi, few outspoken interests existed to obstruct the establishment of national courts. Frequently, in fact, local leaders wanted them. Customary courts had not always been popular, and among local intellectual groups they were regarded with disdain and anger. National courts were prestigious and, of course, a mark of membership in the new independent state. 58 During these early years of independence,

to ten years imprisonment for such an adat crime. Where an adat crime could be matched to a crime in a criminal code, the sentence would conform to the code. The whole drift of these provisions was to give government judges considerable discretion to limit and eventually to change adat criminal law through the gradual extension of the code rules. In fact, however, the criminal code had already gained much currency throughout the country, largely as a result of pressure from Dutch administrative officials in customary courts before the war.

56. Clarification of law $1 / 1951$ in ibid., at pp. 105-6.

57. Customary courts in Sulawesi were abolished by decree of the Minister of Justice, which took effect on Sept. 1, 1952. These included 57 swapradja courts--i.e., those under the authority of the petty rulers of the island who had been selfgoverning on the basis of the korte verklaring (short declaration) with the colonial government--and the adat courts of five formerly directly-governed areas (Gantarang Matinggi, Wanua Waru, Laikang, Kindang, and Gorontolo). The swapradja courts (Raad Kerta) of Bali were abolished by ministerial decree in March 1952 and those of Lombok (Raad Kerta and Raad Sasak) in October 1953. In fact, however, the courts on Lombok had disappeared along with those of Bali through the efforts of the chairman of the Pengadilan Negeri in Bali, who also took charge of judicial affairs in Lombok. For the above decrees see Engelbrecht, Kitab2 Undang2, Undang2 dan Peraturan2 serta Undang2 Dasar Sementara Republik Indonesia (Leiden: Sijthoff, 1954), pp. 1202-3, 2966. On the abolition of adat courts in Sumbawa, Sumba, Timor, and Flores, see Decree of the Minister of Justice, May 19, 1954; for Kalimantan, the Decrees of June 21 and August 18, 1954; for Bengkulu and Rejang, the Decree of December 10, 1956.

58. Looking back on the abolition of kerta courts in Bali, Balinese judges and lawyers generally admit that it was intellectuals, including themselves, who really wanted the new government courts and made their views known to officials from Jakarta. Some of these men admit that villagers in Bali were not deeply 
symbolic participation in the national community through its institutional apparatus was attractive enough to override worries about surrendering local authority and about conflicts between national and local interests. Local ruling groups either remained too weak following the revolution to protest their loss of authority or felt confident that they could in time locally control the influence of national institutions.

Finding judges for the new national courts was difficult. Usually the solution was to appoint at least one law school-trained judge, but for the rest to co-opt former customary court judges, some of whom remained in the Pengadilan Negeri for at least a decade. In Bali and Lombok this worked out admirably. The adat judges, a few of whom had had some professional training in the colony, knew local law and people very we11, and their presence on the new courts facilitated the transitıon. Once they became government judges, however, they were national officials, subject to hierarchical pressure from Jakarta, with the result that another link was created between national government and local society. 59

One major area where adat courts were not immediately done away with was South Sumatra, to which attention will be paid here both because data is available and because the recent history of South Sumatran customary courts illustrates the social and political forces at work in the process of unification.

Had the Dutch not taken South Sumatra in 1948, adat courts there might also have disappeared during the revolution. After the transfer of sovereignty, political conditions in South Sumatra were uncertain, and shortages of judicial personnel offered an easy excuse for avoiding any action. Adat courts themselves had become a pawn in one kind of political conflict. I will not deal with the issue at length here, but it focused on an effort by Islamic groups and the Ministry of Religion to establish new Islamic courts in South Sumatra.60. This required splitting off the Islamic functions of the old adat courts, which would naturally have been easier were the adat courts eliminated. The local opposition to organized Islam was reluctant to see this happen, and so were officials of the Ministries of Interior and Justice, who had no interest in encouraging the expansion of Islamic institutions. Islamic courts were nevertheless established here and there, though often with considerable argument over their legality. But all this was only one part of the adat court problem in South Sumatra.

By the mid-1950's other political issues in Indonesia had begun to take precedence over questions of institutional unification. The

concerned one way or the other. But the intellectuals wanted a national unified judicial system, and they insisted that the customary courts--because they had been supported by the colony, and because they were local, and because they were "primitive" in their procedures--must be eliminated.

59. Where the self-governing (swapradja, zelfbestuur) areas still existed, as in some of the islands of Nusatenggara, they were under the jurisdiction of the Ministry of Interior, with which the Ministry of Justice had to coordinate its efforts. When former customary court judges were appointed to the Pengadilan Negeri, they automatically moved over to the Ministry of Justice. Nearly all of the swapradja areas were eventually abolished.

60. See Lev, Islamic Courts in Indonesia, pp. $84 \mathrm{ff}$. 
regional tensions had al ready emerged that eventually broke out into open rebellion in 1958. Political conflict in South Sumatra was such that it kept the area out of the rebellion against Jakarta. But the period of revolutionary mobilization clearly had passed, and issues were being raised with respect to the defense of local tradition and autonomy against the expansion of the power of the pusat (center)-meaning either Jakarta or Java, depending upon one's perspective and mood.61 So, little was done in Jakarta to deal with South Sumatran customary courts until 1960 .

A great deal happened in South Sumatra itself, however. ${ }^{6} 2$ Even apart from the Islamic factor, adat courts had already been at issue during the revolution, before the Dutch returned, and in much the same way as elsewhere in Sumatra. The period between the surrender of the Japanese and the entry of Dutch forces was one of social and political upheaval, in which men identified with the revolutionary republic challenged the authority of traditional leadership in much of South Sumatra. The central figures in the structure of rural authority in the area were the pasirah, heads of the territorially organized marga, districts that included several villages.63 Under the Dutch the pasirah had become a highly educated, wealthy, and all but hereditary elite group, their elective positions usually descending from father to son or near relative. Before the war urban intellectuals and political leaders had already demanded the abolition of customary courts. Now after 1945 , as political initiative shifted to urban revolutionary centers--mainly Palembang--traditional local leaders and the institu-

61. For example, see the speech by S. Takdir Alisjahbana at the all-Sumatra convention on adat held in Bukittinggi in March 1957, Perdjuangan untuk Autonomi dan Kedudukan Adat Didalamnja (Jakarta: Pustaka Rakyat, 1957).

62. I am concerned primarily with Palembang and the surrounding Pasemah areas, not with Benkulu along the southwestern coast and only slightly with Lampung in the extreme south. Much of the material in this discussion was obtained during a trip to Palembang in August 1960.

63. The prewar administrative hierarchy in South Sumatra consisted from top to bottom of three Dutch officials--the resident, assistant resident, and controleur--and the Indonesian demang, head of a subdistrict (onderafdeeling) and roughly equivalent in rank to a Javanese wedana. Below the onderafdeeling was the marga, which in South Sumatra is a territorial rather than a genealogical designation, as it is among the Batak. The marga is a larger unit than the Javanese desa, though both are basically artificial combinations of villages proper (dukuh in Java, dusun in South Sumatra) reorganized by the Dutch. The adat court system, which the Dutch administration helped to organize during the last two decades of the colony, consisted of a rapat marga, rapat kecil, and rapat besar, following the same pattern used in North Sumatra. Pasirah were the dominant Indonesian officials in each court, though the heads of the dusun, keria, also were member judges in the rapat marga and rapat kecil. As elsewhere in the colony the controleur or assistant resident exercised great influence over these courts, even after they were formally deposed as chairman of the higher tribunals. Decisions of the rapat kecil and rapat besar had to be approved before execution by the Dutch resident, who was replaced during and after the occupation by a rapat tinggi (high or supreme session) located in Palembang and after 1950 subject to Supreme Court cassation. On prewar social organization and customary family law among the Pasemah groups, see W. Hoven, "De Pasemah en Haar Verwantschaps-, Huwelijks- en Erfrecht" (Ph.D. thesis, University of Leiden, 1927). 
tions they controlled came under strong attack. Many pasirah were forced out and replaced by new types of leaders linked to the revolutionary cause. 64 Revolutionary leaders in the region generally agreed that the adat courts must be eliminated. An early republican governor, Abbas, undertook to hold elections for new pasirah and, at the same time, to begin the work of abolishing customary courts. He was forced to leave the area for other political reasons, but the policy was not dropped. In 1ate 1946 or early 1947, after the conference in Pematang Siantar of Sumatra judges, the chairman of the government court in Palembang, Judge Mahadi, who had attended that meeting, called a similar meeting of the few national judges in South Sumatra. They also agreed that all customary courts in South Sumatra should be abolished, as one would expect. 65 It probably would have been done had there been time; but the Dutch took Palembang by mid-1947 and pursued the opposite policy.

Within a few months of the transfer of sovereignty the governor of South Sumatra received a working paper entitled "Towards the Abolition of Native Courts and Judicial Unification in South Sumatra," a copy of which was sent to the Ministry of the Interior in Jakarta, whence it was sent to the Ministry of Justice. It was written by Alwi, former state secretary and head of the department of interior of the defunct (federal) state of South Sumatra.65 It had no noticeable effect on policy, in that the adat courts remained for another decade, but it is worth quoting as representative of the views of many intellectuals, officials, and political leaders in Palembang, and for that matter throughout Indonesia at the time. First, Alwi thought that unless Indonesia's courts met international standards, foreigners might demand rights of extraterritoriality. Second, he argued that the adat courts had not fulfilled the conditions of good justice. They were not based on a separation of functions, nor were they bound by written codes or even such obvious principles of criminal law as that of no punishment without a previous statute. The adat courts were guilty of arbitrariness, and they provided no legal certainty. Alwi offered a number of examples of these faults, all drawn from the colonial period, in which either pasirah or Dutch officials abused their judicial authority. Moreover, as the customary courts were not bound by common rules of procedure and substantive law, the law varied from area to area, and this too increased legal uncertainty. Changes since the revolution, Alwi wrote, made adat courts even less tenable. The colonial controleur did at least possess some legal expertise. But now the pamong

64. The former pasirah, having good educations, social influence, and family wealth, became an important source of South Sumatran political and administrative talent. Many eventually moved into pamong praja positions in the region, and so were able to regain control over the adat courts. Others joined the provincial government, private business, and so on.

65. From an interview with Judge Mahadi in Medan, where he was chairman of the Pengadilan Tinggi, on April 22, 1960.

66. Alwi later became director of agrarian affairs in South Sumatra. The paper was dated March 27, 1950; its title in the original was "Menudju kearah Penghapusan Pengadilan Asli dan Persamaan Pengadilan di Sumatera Selatan." A copy of the paper was found in the Supomo papers, Supomo having been federal Minister of Justice at the time. It should be mentioned that the views of Alwi were shared by many who supported the federal system and those who supported the unitary state alike. 
praja--the wedana (district officer) particularly--were in charge of the adat courts. The rest should be quoted directly:

(These wedana), and all the more so the new ones, know very little or nothing about law, while the member judges [of the rapat], because of the recent removal of the old Chiefs [the pasirah], are also men who know little or nothing about law. . .

As a result of the Proclamation of Independence of August 17, 1945 , in several areas of Sumatra leaders were killed in what were commonly called "social revolutions."

Those killings occurred for the most past in areas where there were customary courts . . . for example in East Sumatra, Atjeh, Tapanuli, and Palembang. We do not think this was mere coincidence, but rather was the consequence of the customary courts. . . .

The argument is probably extreme, calling up images of something like the prerevolutionary parlements in France. Adat courts were indeed often unpopular, but more so in some areas than others. What evidence there is suggests that they were probably more unpopular wherever the spread between ruling groups and subjects was not bridged by kinship or other kinds of ties. In any case, Alwi's argument, a common one after the revolution, is intriguing. It is that while the prewar rural elite was unacceptable because of its arbitrariness, the postrevolutionary local elite was unacceptable for its lack of experience and expertise. Therefore, the only choice was to call upon national institutions, which the myths of the revolution and of the modern state promised would be efficacious on all grounds. Alwi summed up his position against adat courts and in favor of government courts with a reference to the colonial policy of judicial pluralism:

Colonialism is no more. The intellectual leaders of Indonesia hold the view that the native courts and the differences between courts [of the colonial period] mentioned above are related to colonialism.

In order for that colonialism to die completely without leaving any traces, and also in order to achieve equality of rights, equality of races, and equality of status, it is altogether fitting that the remaining native courts . . . be done away with.

Equal Justice under Law [English in the original] is our goal.

One kind of law... . and one kind of court for all the people of Indonesia.

This was a reasonable description of the intellectual aspirations of leaders who had become part of "national" Indonesia.

It has been mentioned that nothing came of this plea for eliminating the adat courts. But a long and tense struggle developed between those who inherited control of the adat courts and those who sought to abolish them. The rapat kecil and rapat besar were led now by the wedana, district officers in the centrally-directed regional bureaucracy that had expanded outwards from Java over all of Indonesia. Some of these wedana in South Sumatra had entered the pamong praja as local revolutionary leaders. Not surprisingly, they became the chief defenders of adat courts.67 The courts gave them considerable

67. In 1960 Governor Bastari of South Sumatra kindly permitted me to examine a file of correspondence concerned with the adat court issue. I want to thank him for 
power, and in some cases wealth, and made their administrative functions easier. In addition, other support for the adat courts came from groups whose interests and perspectives were increasingly defined by regional administrative, cultural, and political concerns, and for whom the central government's capabilities and intentions had become threatening. Some provincial and local administrators feared that abolishing adat courts without adequate replacement would cause social hardship and disruption, especially in areas far from the kabupatèn capitals where the new Pengadilan Negeri would sit. From a quite different point of view, as regional tensions rose in the mid-1950's, South sumatran patriots objected to eliminating the adat courts on crounds that this would weaken local tradition and customary law. One frequently heard such views from local leaders who opposed "Javanese imperialism" and the expansion of Jakarta's authority over local affairs. Finally, army officers from the divisional level downwards began to give support to the adat courts after 1957 , when national martial law gave the regional army command a great deal of administrative authority over civilian affairs. Two related considerations may explain the military perspective on this issue. On the one hand, local army commanders wanted to maintain stability in rural areas, which they assumed might be disrupted by the removal of the traditional courts. On the other hand, largely out of the same concern for stability but also because of a developing alliance of sorts between the army and the pamong praja, army leaders were reluctant to see the pamong praja weakened by loss of the rapat. 68

it here. Much of my discussion is based on this correspondence, which took place from 1957 through mid-1960 between the governor's office and pamong praja officials, prosecution officers, the Ministries of Justice and Interior, and the Supreme Court. In the file the only letters arguing that the rapat should be retained were written by two wedana from Banyuasin and Musi Ulu, in response to a request from the governor to local pamong praja officials for information on the views of the people concerning adat courts. The letters were dated January 16 and August 8, 1958. They maintained that local people would be disappointed if the adat courts were removed, that judges on the rapat--particularly the wedana themselves--knew more about the written law than they were given credit for, and that instead of being eliminated the adat courts should be improved. Additional information on adat courts was obtained in interviews with the clerk of the rapat tinggi in Palembang, a former pasirah, a wedana from Musi Ulu, several Pengadilan Negeri judges, and officials in the provincial government. The charge that wedana in control of the adat courts lacked legal knowledge was not always just. Some, indeed, especially former pasirah, were extraordinarily capable and well trained men. Moreover, as the decisions of the rapat kecil and rapat besar had to be examined by the rapat tinggi, whose chairman was also chairman of the Pengadilan Negeri in Palembang, some control was in fact exercised. Increasingly from 1950 on the rapat were held to the rules of the criminal code (KUHP) and the procedural code (HIR). It is also worth suggesting that the charge of inadequate legal knowledge was not always relevant to the needs of local populations, for it reflected the institutional interests and skills of national bureaucratic organizations and did not really meet logically the problem of local administrative arbitrariness. But this is an incidental point.

68. This tacit alliance was nationwide. The pamong praja had been threatened with extinction by a new decentralization law (Law 1/1957) supported by national political parties, which would gain power by confining the bureaucracy. Not long after the national state of siege was proclaimed in March 1957, however, army leaders in Jakarta and elsewhere began to support the pamong praja, and 
Opposition to adat courts was similarly impelled by a mixture of interest and ideology. Locally elected regional councils (DPRD) tended to favor abolition of adat courts in order to weaken the pamong praja.69 Moreover, a Pengadilan Negeri would lend the prestige of a modern, national institution to the kabupatèn. Outspoken opposition to adat courts also came from urban intellectuals, private advocates, provincial political and administrative leaders--including the governor--and generally those parts of the bureaucracy linked directly with Jakarta through national institutional hierarchies. For provincial political leaders and administrative officials, abolishing the adat courts would perform the double service of reducing the power of lower local officials and satisfying the urge to acquire a fair share of national institutional 1inks. Prosecutors had a special interest in new Pengadilan Negeri, which would expand their authority. The same, of course, was true of government judges, who moreover tended naturaliy to emphasize the advantages of government courts over customary courts --though older judges often worried about adequate replacement of the adat courts and were less inclined to ideological judgments of them.

In 1960 the Ministry of Justice finally abolished the adat courts of South Sumatra, along with those that remained in Jambi, Riau, the Moluccas, and a few other places. South Sumatra was the key area in this final phase of unification. Governor Bastari, who had opposed the adat courts of South Sumatra even before the war, made his strong views known in Jakarta from the time he became governor of the province in the late $1950^{\prime} \mathrm{s}$. But local opposition to the adat courts found equally important support from the ideological tenor of Guided Democracy, whose symbolic emphases, as in the revolution, were decidedly on national unity. Local impetuses were again able to connect with unifying signals from the national center. Without this, perhaps, the adat courts would have lasted longer.

As an anticlimax, administrative problems set in almost immediately once the adat courts were abolished. There were not in fact enough judges to staff new national courts. Several pamong praja officials applied for judgeships, and bureaucratic leaders in Palembang

eventually the policies indicated by Law 1/1957 faded. By 1959 army officers had begun to be appointed to pamong praja positions, which of course made its disappearance even less likely. On the postrevolutionary pamong praja and regional government generally, see John Legge, Central Authority and Regional Autonomy in Indonesia (Ithaca: Corne11 University Press, 1961).

69. The regional legislative councils (DPRD) of Ogan and Komering Ulu kabupatèn passed a resolution on May 17, 1957 to the effect that the continued existence of the adat courts would unfavorably influence the legal development of society and therefore ought to be done away with as soon as possible. A similar resolution was passed by the legislative council of Lahak kabupatèn on December 28 , 1957. A few days earlier, on December 19, 1957, the bupati (regent) of Lahat wrote to the resident of Palembang advising quick abolition of the adat courts, though in guarded language suggesting that most people simply wanted speedy justice and that the adat courts could not always supply this. Moreover, he said, people with a "sense of law" (kesadaran hukum) wanted to have Pengadilan Negeri instead of adat courts. It is possible either that the bupati himself wanted the adat courts abolished or that pressure had been brought to bear on him by the legislative council. Bupati were involved in the customary courts to the extent that they might examine all decisions sent to the rapat tinggi and, when they felt it necessary, append their advice. 
were eager to accommodate them, partly in order to have judges but also to buy off the recalcitrant wedana. But the Supreme Court rejected older pamong praja applicants, and the younger ones--who sought promotion and status by joining the national courts--were not permitted by the Ministry of Interior to leave their posts. Moreover, new Pengadilan Negeri were established in only three of the six kabupatèn in Palembang residency, while local officials had hoped for at least six and wanted more. These were problems that could be solved in time, however, as the judiciary acquired more personnel. In the meantime, local officials undoubtedly filled in with informal arrangements to settle disputes. Another problem was more delicate, and only research can tell how it has been handled. Government courts might not be able to perform all the functions that adat courts had once managed. Lawyers, judges, and administrators who felt deeply about unification, also sometimes worried that government courts might lack something that the old adat courts, whatever their faults, had provided. The then chairman of the Supreme Court, Wirjono Prodjodikoro, recognized this difficulty in a statement to judges of the new Pengadilan Negeri, whom he admonished to be flexible and informal in their approaches to local law.

North Tapanuli: An Attempt to Restore Adat Courts

The issue of function--how well courts serve the legal needs of society--formed the rationale of one serious attempt, in 1952 , to reconstruct a local customary jurisdiction. There may have been such efforts elsewhere in Indonesia after the revolution, but this one left behind a fascinating document. It is the report of a committee created by the provisional regional council (DPRDS) of North Tapanuli, the area of the Toba Batak, in order to examine the possibility of reestablishing a system of local courts. 70 My discussion here is based largely on this report.

What makes the document so interesting is that it reflects accurately the kinds of second thoughts about unification that occurred after the revolution, and the complexity of local interests and national symbols that people had to deal with in working out their relationships with the new state. Thus prewar adat courts were condemned--the people despised them, said the report--because they were actually controlled by the colonial administration, which used them to exploit Batak society. ${ }^{71}$ But at the same time there were many courts, and

70. The report, which I found in the library of Parliament in Jakarta, was printed as a pamphlet under the title Sekitar Soal Peradilan dan Hakim Perdamaian compiled by the Komisi Memeriksa Hukum Adat Istiadat (Commission for the Investigation of Adat Law). The chairman of this commission was S. M. Simandjuntak. F. Pasaribu, bupati of Tapanuli Utara at the time, wrote a foreword for the report dated November 8,1952 . On a research trip to Balige in 1960 I was unable to find further material on the issue; while a few men remembered it vaguely, none whom I talked with knew much about it.

71. See Vergouwen, Customary Law of the Toba-Batak, on which the writers of the report relied for some of their analysis. It bears repeating that the adat courts of Tapanuli were not in fact village-controlled during the late colonial period; government administrators participated in and no doubt usually dominated them. 
people could always have their day in court. Similarly, according to the report, national unification was certainly a good thing and everyone favored it, but then perhaps some exceptions ought to be made for the sake of local needs. The writers of the report avoided any appearance that their institutional questions contained doubts about the essential rightness of the revolution, independence, the new state, national unity, and central institutions.

Yet there were serious problems. The old adat courts finally disappeared in 1948 , but they were replaced by only one first-instance national court (Pengadilan Negeri) for all of North Tapanuli with a scattered population of about 700,000. (Pengadilan Negeri are distributed one per kabupatèn; North Tapanuli was a single kabupatèn.) What was worse, the court was terribly understaffed, with only one judge. Moreover, while before the war there were two appeals courts in Sumatra, in Medan and Padang, now only one appellate instance (Pengadilan Tinggi) served the whole of Sumatra, and it too was understaffed. Consequently, people with civil disputes could not get them settled quickly by a government court. Without due resolution, these conflicts might grow long and bitter, traveling through the veins of the patrilineal kinship order of the Toba Batak. The report argued that the Toba were prone to such long-lasting and disruptive fights, and described two of them out of the past. People who waited too long for a decision and then were disappointed by another long wait for an appeal, might well try to take justice into their own hands. To deal with this problem, the committee proposed that the Ministry of Justice appoint a chairman--still lacking in 1952--of the Pengadilan Negeri and at least four more first-instance judges, so that one could sit in each former onderafdeeling (subdistrict) in North Tapanuli: Toba, Samosir, Humbang, Silindung, and Dairi. It suggested further that more appellate judges be appointed. The report also urged a simplification of court procedure, so that village litigants would not have to rely on advocates or bush-lawyers.

It was not, however, merely the insufficiency of courts and judges that caused trouble. The problem of procedure came closer to the complex core of the matter. Part of it was that most people had no way of understanding the formal procedure of the new government courts. Such was the complexity and oddness of it, the report complained, that many people finally assumed it must really be a matter of bargaining, with victory going to whoever paid the right price. Procedural simplicity would help. But simplicity would not solve the more difficult problem that government courts simply were not connected with the most critical dispute-settling context in Toba Batak society--the kinship structure.

The writers of the report carefully explained Toba Batak family structure, indicating the extent to which relationships between wifegiving and wife-receiving marga contributed to keeping the peace. These relationships were crucial in resolving conflicts; and if they were ignored in a dispute, serious consequences might follow. For this reason, conciliation and compromise were essential in Toba litigation, and the report pointed out a few times that the Batak people were inclined to be litigious. Most cases that reached court were not criminal--of these there were few--but minor civil disputes within the family. Now, in the Pengadilan Negeri, judges often could not know the full background of such disputes, and their case-1oad and procedural requirements did not permit them the time or spirit to make adequate inquiry. Furthermore, while government judges did ask litigants 
whether they were willing to work out a compromise, in the nature of it this must be a perfunctory question; the government court did not have the social resources and knowledge at its disposal to wait litigants out and lead them towards conciliation. 72 As the formal court was not intimately involved in local village and kinship life, it had no compeliing interest in the provenance of disputes nor in the aftermath of mere judicial--rather than social--resolutions.

With all this in mind, the regional council of North Tapanuli asked the local Pengadilan Negeri judge--himself a Toba--whether the national government would legally create a system of village courts hakim perdamaian, literally conciliation judges--in which the pamong praja would be involved to some extent and whose work might even be subject to control by the Pengadilan Negeri. ${ }^{73}$ Not altogether surprisingly, the judge firmly said no, that emergency Law $1 / 1951$ had already abolished adat courts, and the hakim perdamaian now proposed were essentially adat courts. The legal arguments over this issue need little attention here. The Pengadilan Negeri judge obviously felt that the logic of a unified national judiciary excluded local courts; that is what unification meant. He added defensively that the Pengadilan Negeri was surely adequate to all the problems that came before it. In the $1930^{\prime} s$ the government bureaucracy would not release its control over adat courts in Tapanuli and other directly-governed areas; to do so would have diminished bureaucratic authority over village affairs. In the $1950^{\prime}$ s the government judiciary, and other national institutions, were similarly reluctant to allow much autonomous authority to local leadership.

Despite the advice of the Pengadilan Negeri judge, the committee on adat courts went ahead anyway to propose a system of local courts, as well as improvements in the staffing and procedure of government courts. Nothing came of it. The Ministry of Justice either did not respond or refused, and in time the issue was dropped.

It is worth exploring the anxieties behind the hakim perdamaian proposal further, especially as they relate to wider issues of national unification and local autonomy. In part, no doubt, local Toba leaders were deeply concerned over the procedural inadequacy of government justice. They understood better than outsiders that village leadership

72. Article 130 of the procedural code (H.I.R.) requires first-instance judges to try to conciliate civil litigants before proceeding with a hearing. Usually, however, the attempt is mechanical, almost in the nature of a ritual question. Only a judge of extraordinary character and social influence can often bring litigants to a compromise in court, because going to court is itself an act of considerable hostility.

73. The choice of the term hakim perdamaian, not indigenous to North Tapanuli, was dictated by the wording of article 1 para. 3 of Emergency Law 1/1951 on the organization, powers, and procedure of civil courts. Article 1 (3) provided that the abolition of adat courts intended by article 1 (1) and 1 (2) did not apply to existing village hakim perdamaian. See note 54 above. Ministry of Justice officials assumed that hakim perdamaian were basically informal, and existing statutory provisions permitted them only to mediate disputes, not to render decisions. The committee on adat courts in North Tapanuli attempted to reinterpret article 1 (3) of the 1951 law to mean that hakim perdamaian could be created, and further that they might be reconstructed into courts. The interpretation was easily shown to be legally invalid. 
could rely on Batak kinship organization to resolve local disputes peacefully. Yet much of this village leadership, and local leadership generally, was new and perhaps less authoritative than before the revolution. It may be that one purpose for proposing new local courts was to begin consolidating the authority of local leaders after the revolution. ${ }^{4}$ Significantly, the regional council hoped that the national government would authorize by law the creation of the hakim perdamaian. Toba leaders were not about to set up village courts on their own authority; they felt compelled to accept the symbols of national political legitimacy. In addition, however, a national statute would give legal authority to the new courts where traditional authority was 1acking. By analogy with Islamic courts, the committee also suggested that hakim perdamaian decisions be made executable by decree (executoire verkzaring) of the Pengadilan Negeri, another indication that Toba leaders feared that local institutions could not make it entirely on their own and would need some national institutional support. The going themes of national institutional development made such support unlikely.

There is some evidence in the report that Toba leaders were even more worried about a question with wider implications for traditional Batak culture. The disappearance of local judicial institutions and the imposition of new national courts suddenly opened Toba culture to the threat of rapid change forced from the outside. Local institutional buffers and defenses were gone. Toba leaders quite rightly felt like a minority in a huge Indonesian state dominated by Javanese, Sundanese and others who had little reason to be overly sympathetic to Batak institutions--hence the report's effort to explain Toba patrilinealism to an audience whose kinship pattern was bilateral. At one point in the report, its authors took up the question of local adat criminal law. There were national criminal code delicts that local adat did not recognize, and some in local adat that did not exist in the criminal code. ${ }^{75}$ So far the potential hardship of this situation has been avoided, because local police and prosecutors understood Batak language and adat criminal law--that is, they themselves were Toba. But what about the future? The report urged that police and prosecuting officials, and by implication government judges, should always be chosen from among those who spoke the local language and understood the adat.

The fear that national unification must lead to powerful pressure for change turned out to be realistic. It was (and is) not a simple

74. The report noted that village chiefs are responsible for village security and order, including the settlement of minor conflicts, for which there was legal support in article 13 of the H.I.R. The committee argued that creating the hakim perdamaian would strengthen village leadership. "The pamong desa [village administration] should have certainty of position and responsibility so that it can settle such disputes as may cause disharmony in the village" (p. 43 of the report).

75. For example, kidnapping a girl with the intention of marrying her is not an adat crime, but would be considered so in the national criminal code. Also, a pig found ruining paddy in the field, or an adulterer, may be killed without legal consequence in local adat 1 aw, but not according to the criminal code. Adat crimes could be tried by analogy to similar crimes in the criminal code, but this put a great deal of discretionary authority into the hands of local prosecutors, who might or might not be native sons. 
matter of change being forced by outside powers and influences, as some interpretations would have it. Rather, local interests in various kinds of social change were able to link up with outside pressures moving in more or less the same direction. Novel cultural impulses emanating from the major cities of Indonesia were hard to avoid. And, more noticeably, national institutions tended inevitably toward centralization of standards. In the national judiciary this meant that local adat received less and less attention, while the rules of the exemplary center received more and more. The place of adat in Indonesian legal practice, and therefore increasingly in legal ideology, declined precipitately. New adat law research became rare. Law students showed much less interest in it. And the judges of the Supreme Court and appeals courts began to assume not only that local adat was changeable, but that they were peculiarly responsible for changing it. By the late 1950's and early 1960's--again, during the period of Guided Democracy, when ideological emphases were heavily on national unity--the Supreme Court's family 1aw jurisprudence took a distinctly integrating and unifying turn. Batak family 1 aw rules bore the brunt of the challenge, new decisions being based on bilateral assumptions about inheritance that threatened, as least symbolically, the very heart of the patrilineal kinship structure. ${ }^{76}$ Public protest meetings organized in Medan may have encouraged the Supreme Court to go more slowly, but they did not stop the trend.

By this time, local groups had only a few (though often effective) alternative means of defense against the challenge of national institutions and central public policy. One, for example, was simply to ignore, avoid, or undercut national law in any way possible. Another was to build up regional political alliances that offered bargaining power to hold off outside pressures. Still another, within the legal system, was to rely on tendencies in national bureaucratic institutions to develop buffers of a sort. Thus first-instance judges are more responsive to local pressures than Supreme Court judges, and appellate judges rest somewhere in the middle of a wide scale of responsiveness. The pressures are for change as well as the status quo, but both kinds of pressure must focus now, in some measure, on national institutions.

In the process of unification, functional issues, while they were raised, were usually secondary. People argued about the advantages of adat courts and government courts, but the debate, such as it was, seemed only incidentally relevant. How and in what way old or new courts better served the legal needs of the people is a hopelessly complicated question, because what the "legal needs of the people" are depends on the perspective one adopts, and often enough the perspective is necessarily ideological. More at issue than function were the struggles for legitimate authority between local, regional, and nation-. al elites, struggles in which institutional power and symbols were critically important. The occupation and revolution, by breaking

76. See Daniel S. Lev, "The Supreme Court and Adat Inheritance Law in Indonesia," American Journal of Comparative Law, XI, No. 2 (1962), pp. 205-24, and my essay "Judicial Institutions and Legal Culture," in Claire Holt, Culture and Politics in Indonesia (Ithaca: Cornell University Press, 1972), pp. 309 ff. Also M. A. Jaspan, "In Quest of New Law: The Perplexity of Legal Syncretism in Indonesia," Comparative Studies in Society and History, VII, No. 3 (April 1965), pp. 252-66 and the commentary on Jaspan's article by Paul Stirling in the same journal, VIII, No. 1 (October 1965), pp. 50-55. 
existing patterns of authority, made these struggles inevitable. Nearly everywhere in the country during the revolution ruling groups were crushed, pushed aside, or at least challenged and shaken. Many eventually returned to authority, it is true, and sometimes with about as much power as they had exercised before, despite the appearances of new institutional patterns. But the distribution of institutional authority was revised, and the impetus given by the revolution to national organization had profound consequences for local autonomy and local culture. 